\title{
Pseudocoordination with 'take' in Baltic and its neighbours
}

\author{
Nicole NaU, \\ Vilnius University \\ \& Adam Mickiewicz University in Poznań \\ Kirill Kozhanov, \\ Vilnius University \\ LIINA LINDSTRÖM, \\ Vilnius University \& University of Tartu
}

\author{
Asta Laugaliené, \\ Vilnius University \\ Pawee Brudzyński, \\ Vilnius University \& University of Warsaw
}

This paper is the first empirical study of the construction TAKE (and) V ("he took and left" = 'he left suddenly, unexpectedly') in contemporary Latvian and Lithuanian, carried out on a large sample of corpus data. The results obtained for Baltic are compared with Slavic (Polish, Russian) and Finnic (Estonian, Finnish) data from comparable corpora. It is argued that out of all the languages under consideration, in Baltic the construction is the most frequent and the most fixed in its form, while at the same time being able to appear in various inflectional forms and in various functions. Other languages differ in how they deviate from the Baltic type. It is also shown that its semantics is largely context-dependent, being sensitive to the semantics of the inflectional form, subject and type of the lexical verb.

Keywords: pseudocoordination, hendiadys, Latvian, Lithuanian, Estonian, Finnish, Russian, Polish, corpus linguistics

\section{Introduction ${ }^{1}$}

A construction of the type TAKE (and) $\mathrm{V}$ is found in almost all languages of Europe. In this paper we explore and compare the formal and functional characteristics of this construction in six languages: Latvian, Lithuanian,

\footnotetext{
${ }^{1}$ The empirical research reported in this paper was carried out by one expert per language with additional support by other members of the team: Latvian - Nicole Nau, Lithuanian - Kirill Kozhanov, Estonian - Liina Lindström, Finnish - Asta Laugalienè, Polish-Paweł Brudzyński, Russian-Kirill Kozhanov. Sections 1, 2 and 6 were written by Nicole Nau; Section 3 was written by Nicole Nau and Kirill Kozhanov, Section 4 by Liina Lindström, and Section 5 by Kirill Kozhanov. We would like to thank our reviewers as well as members of the project The Baltic Verb: Grams, Categories and Domains for support and helpful comments, and Piotr Wyroślak for help with the Polish data and statistics. Special thanks are due to Daniel Ross, who provided us with many valuable questions and comments. This research has received funding from the European Social Fund (project No. 09.3.3-LMT-K-712-01-0071) under grant agreement with the Research Council of Lithuania (LмтLт).
} 
Estonian, Finnish, Polish and Russian. Our focus will be on the two Baltic languages. Examples (1) and (2) illustrate typical instances of the construction.

(1) Latvian (Latvian-English dictionary at letonika.lv, sub ņemt 'take')

viņš ņēma un aizgāja
3SG.NOM.M take.PST.3 and PVB.go.PST.3
'he just left' (meaning 'he simply left')

(2) Lithuanian (DLKž, sub imti 'take')

$\begin{array}{llll}\text { ima } & \text { ir } & \text { atsidaro } & \text { durys } \\ \text { take.PRS.3 } & \text { and } & \text { PVB.RFL.open.PRS.3 } & \text { door.NOM.PL } \\ \text { 'the door opens (unexpectedly)' } & \end{array}$

In this construction, a verb with the lexical meaning 'take' does not refer to a separate action of taking, but rather modifies another verb or verb phrase, to which it is formally coordinated. In the investigated languages, the construction most often contains the coordinating conjunction 'and'. Asyndetic coordination (or juxtaposition) without a linking element is also possible, but it is less frequent and in Baltic it decidedly plays only a minor role.

Our first aim is to give a thorough description of this construction in the contemporary Baltic standard languages, where it has been very poorly documented and described until now. We then present the construction in the two Finnic and the two Slavic languages according to the same scheme, but in lesser detail. For all languages we use data from comparable corpora compiled from Internet resources. The intriguing questions for the subsequent discussion are what is cross-linguistically common to the construction, where individual languages differ, and how both similarities and differences may be explained. While, as mentioned above, the TAKE and V construction is found in almost all languages of Europe (and beyond), it has both area- and language-specific features, which are not yet well studied and understood. In this paper we will give a profile of the construction in a north-eastern cluster of European languages which in future studies could be compared, for example, to a Scandinavian or a Romance (south-western European) profile. It will turn out that the Baltic languages have a central place in this profile.

In Section 2, we describe the sources and the methods of data selection, which includes the non-trivial question of how to distinguish our construction from other occurrences of a sequence ['take' 'and' V]. In Section 3, we present and discuss in detail the forms and meanings of the 
construction in Baltic as found in the corpora. Sections 4 and 5 summarise the findings on the Finnic and Slavic languages. Section 6 discusses the similarities and differences among the six languages and sums up our most important findings.

In the remainder of this Introduction we will give a short overview of previous research on TAKE and $\mathrm{V}$ and related construction.

Constructions as the one investigated here have been discussed in the linguistic literature mainly under two terms: VERBAL HENDIADYs (Poutsma 1917; Hopper 2002; Taube MS) and PSEUdOCOORDINATION or PSEUdOCOORDINATION (Wiklund 1996; Ross 2016; Ross forthcoming). More recently, they have been considered as a kind of, or as being related to, SERIAL VERB CONSTRUCTIONS (Hopper 2008; Ivulāne 2015; Andrason 2018; 2019). At least some subtypes of the construction were also discussed as part of DOUBLE VERB CONSTRUCTIONS (for Russian, cf. Weiss 2007). For more details on the history of research on these constructions and the diverse terminology see Ross (2014; 2016; forthcoming).

The term HENDIADYs (after Greek $\ddot{\varepsilon} v \delta$ iò $\delta$ voĩ $v$ hen dia dyoin> 'one by means of two') draws attention to the fact that a single action is expressed by two verbs, but it does not suggest or question a specific relation between the two verbs. On the other hand, the term PSEUdocoordinATION highlights the fact that what looks like coordination does not meet all semantic and formal characteristics of typical coordination. One line of research, especially based on Germanic languages, has looked in more detail at these characteristics, often from a formal linguistic perspective (for example, Wiklund 1996; Biberauer \& Vikner 2015). However, the term is also used in works on other aspects of the constructions and has become the most familiar term for this type of constructions.

Apart from verbs meaning 'take', several other verbs are used in pseudocoordination in European languages. In many languages, including English, we find motion verbs such as 'go' and 'come' (for example, Kinn 2018 for Norwegian; Škodová 2009 for Czech; Pulkkinen 1966 and Airola 2007 for Finnish, Tragel 2017 for Estonian). In Baltic, constructions with 'go' are attested and deserve a separate investigation (for Latvian, see Ivulāne 2015). They are more restricted and less frequent than constructions with 'take'. Another group, notably found in Scandinavian languages and Dutch dialects, is verbs of body posture, such as 'sit', 'stand', 'lie' (Haslinger \& van Koppen 2003; Kvist Darnell 2008). Other verbs are mostly found in individual languages, for example Norwegian drive 'carry on' (Lødrup 2017). 
Pseudocoordination with 'take' as the first verb is found in almost all languages of Europe and neighbouring areas. Ross (2017) states that it is "possibly the most wide-spread expression in Eurasia" ("Posiblemente la locución más extendido en Eurasia”, Ross 2017, slide 50). Furthermore, it may be the only type of pseudocoordination in a language. This latter finding however has to be taken with some caution, as these constructions are often not described in grammars and speakers may not be aware of their existence.

The wide spread of TAKE (and) V has drawn the attention of researchers since the 19th century (see Ross 2014 for references), and various hypotheses about its origin and development have been put forward. In a seminal paper written in German and later translated into Spanish, Coseriu (1966; 1977) puts together the results of a vast number of studies where the construction was mentioned or, less often, described in some detail for individual languages or a group of languages. He also reviews several hypotheses about its origin and proposes his own, attributing a major role to Greek and a spread through Bible translations. Following the title of his paper, the construction was later sometimes named by the Spanish phrase tomo y me voy (see Ross 2017 for an overview of research following Coseriu). Coseriu's paper could have been an excellent start for further comparative research, but this did not happen. For the rest of the 2 oth century, the construction was only sporadically studied by individual researchers. In the past twenty years, TAKE and V, and pseudocoordination in general, have again gained the attention of linguists, most of them investigating a single language, more rarely comparing or contrasting two languages. Constructions with movement and posture verbs were studied more often than constructions with 'take'. A comprehensive cross-linguistic study of pseudocoordination from a typological point of view is currently being undertaken by Daniel Ross (forthcoming). As part of his research he updated and complemented Coseriu's study on tomo y me voy (Ross 2017). He found that the construction is attested in more than 60 languages of Europe and Eurasia and concluded that no plausible theory of a single origin and direction of spread can be established.

The presence of the TAKE (and) V construction in Baltic was noted already by Fraenkel $(1921,54-56 ; 1926)$, but it has rarely been treated by later researchers. Ambrazas (1965) discusses it from a historical point of view in relation to an older Lithuanian construction where TAKE has the form of a past participle (literally 'having taken and V'). Ivulāne (2015) is exceptional 
in discussing the construction in a modern Baltic language from a purely synchronic point of view. For her, it is the most likely candidate for an emerging serial verb construction in Latvian. The construction is not mentioned in grammars, but it is documented in monolingual dictionaries (LVV and LLVV for Latvian; LKŽ (sense VII.2) and DLKŽ (sense 14) for Lithuanian).

For Finnic languages, the situation is slightly better. Lewy $(1937 ; 1951)$ drew attention to the construction in Mordvin and cited parallels in Finnic as well as Slavic and North Germanic languages. Pulkkinen (1966) has found TAKE (and) V in all Finnic languages and has characterised it as an old feature in these languages. He discusses parallels with Russian, but based on its distribution also in western dialects, he concludes that it is probably not a calque from Slavic, but an outcome of a natural process of development of the basic meaning of 'take' (Pulkkinen 1966, 211-213). Also Tragel (2003; 2017) found that TAKE (and) V, similar to other serial verb constructions, is an old feature in Estonian and a result of a grammaticalisation process whereby TAKE has lost its transitivity. The construction is mentioned in the comprehensive Finnish grammar (Hakulinen et al. 2004, 1041).

In Polish, the construction with 'take' was mentioned along other constructions consisting of two verbs in the 1970 s by Bąba \& Mikołajczyk (1974) and by Bartmiński (1978). In recent years, several Polish researchers have briefly discussed the construction with wziać ' take' in the imperative (wez), which is the most characteristic form of the construction in Polish (Komorowska 2008; Góralczyk 2010; Gębka-Wolak 2012; and others). Zinken (2013; 2016) analyzed the construction weź V-imperative within an interactional approach. A comprehensive overview of TAKE (and) V in Polish is given in two recent articles by Andrason. Andrason (2018) looks at the construction wziać $\mathrm{V}$ (without conjunction) in more detail and argues for its status as a serial verb construction. In a following paper (Andrason 2019), the author analyses the pseudocoordinative construction and discusses which characteristics it shares with prototypical serial verb constructions.

Russian is the language best documented and described in our sample. The TAKE (and) V construction is mentioned in dictionaries and grammars (see Stojnova 2007 for a short overview). Formal and semantic properties are discussed in Fortuin (2000, 149-161); Stojnova 2007; Weiss (2007). Grammaticalisation of the construction is discussed at length in Kor Chahine (2007) and to some extent in Weiss (2007). Fortuin (2000, 155-161) examines the difference between the TAKE (and) V construction and the so-called narrative imperative, which in Russian can have similar meanings. 


\section{Data and method}

Our point of departure is the construction in the form TAKE (and) V, where TAKE stands for the lemma with the most general meaning of 'take', and consequently the most frequent verb with this meaning in the respective languages. Other verbs of taking (with more specific meanings such as 'grab', 'grasp' or 'catch') may also sometimes occur in pseudocoordination, but they are not considered in the present study. In the Slavic languages, perfective and imperfective verbs had to be taken into account, and for Estonian we also considered the phrasal verb kätte võtma lit. 'take into (one's) hand', which in the course of our study turned out to represent TAKE in our construction far better than the simple verb võtma. For 'and' there is some variation in Russian and to a lesser degree in Estonian, while the other four languages have one straightforward choice. V stands for any lemma tagged as verb.

For data collection we used large, web-based, automatically tagged corpora on the platform Sketch Engine (sketchengine.eu). For five of the languages this was a corpus of the TenTen series - a family of comparable corpora compiled from Internet resources using the same methods (Jakubíček et al. 2013). Unfortunately, the Lithuanian corpus of this series is not morphologically annotated, so for Lithuanian we used a smaller corpus of the WaC series (Kilgarriff et al. 2010), a predecessor of the TenTen series, compiled with similar methods. For names and sizes of the corpora see References. Despite their different size we found these sources more compatible than other corpora that exist for the languages under investigation. They contain the same kinds of texts, especially in the more informal registers in which our construction is mostly found.

In an initial query we searched for all occurrences of a sequence ['take' 'and' V], with the lemmas for 'take' as described above and shown in Table 1. These raw observations were filtered manually to obtain those instances that represented pseudocoordination. For Latvian and Lithuanian, all observations were considered, while for the other languages we worked with random samples of 1000 observations. The filtered samples are the basis for most of our analyses. For certain questions - concerning among others negation, object placement, or the role of the asyndetic variant - additional queries were made. This will be made explicit in the text.

Table 1 presents the number of hits for the initial query and the size of the samples. The last column gives a first indicator of the convention- 
alisation of the construction, in other words, the degree to which a string ['take' 'and' V] represents a construction as a constant pairing of form and meaning.

Table 1. Number and weight of raw and filtered corpus data

\begin{tabular}{|c|c|c|c|c|c|}
\hline $\begin{array}{l}\text { Language, } \\
\text { construction }\end{array}$ & $\begin{array}{l}\text { Initial } \\
\text { query }\end{array}$ & $\begin{array}{c}\text { per } \\
\text { million }^{2}\end{array}$ & $\begin{array}{c}\text { Unfiltered } \\
\text { sample }\end{array}$ & $\begin{array}{c}\text { Filtered } \\
\text { sample }\end{array}$ & $\begin{array}{c}\% \text { of } \\
\text { unfiltered }\end{array}$ \\
\hline Latvian ņemt un $\mathrm{V}$ & 3276 & $5 \cdot 7$ & 3726 & 3093 & $83.0 \%$ \\
\hline Lithuanian imti ir $\mathrm{V}$ & 1003 & $15 \cdot 76$ & 1003 & 943 & $94.0 \%$ \\
\hline Estonian võtma ja $\mathrm{V}$ & 4573 & 13.9 & 1000 & 89 & $8.9 \%$ \\
\hline $\begin{array}{l}\text { Estonian võtma } \\
\text { kätte ja } \mathrm{V} \\
\text { võtma kätte [] V }\end{array}$ & $\begin{array}{l}658 \\
764\end{array}$ & $\begin{array}{l}2.0 \\
2.3\end{array}$ & 500 & 480 & $96.0 \%$ \\
\hline Finnish ottaa ja $\mathrm{V}$ & 8923 & 5.2 & 1000 & 531 & $53.1 \%$ \\
\hline Polish wziać $i \mathrm{~V}$ & 8360 & 0.9 & 1000 & 670 & $67.0 \%$ \\
\hline brać $i \mathrm{~V}$ & 8048 & 0.9 & 1000 & 267 & $26.7 \%$ \\
\hline Russian vzjat' $i \mathrm{~V}$ & 84843 & 4.64 & 1000 & 817 & $81.7 \%$ \\
\hline brat' $i \mathrm{~V}$ & 21271 & 1.16 & 1000 & 454 & $45.4 \%$ \\
\hline $\begin{array}{l}\text { Russian variants } \\
\text { vzjat' da } \mathrm{V} \\
\text { vzjat' da } i \mathrm{~V} \\
\text { brat' da } \mathrm{V} \\
\text { brat'da } i \mathrm{~V}\end{array}$ & $\begin{array}{l}4824 \\
10573 \\
503 \\
76\end{array}$ & $\begin{array}{l}0.26 \\
0.58 \\
0.03 \\
<0.01\end{array}$ & & & \\
\hline
\end{tabular}

As described above, the essence of a hendiadic construction is the expression of a single action by two verbs. This was our main criterion to determine whether a given observation in the raw sample represented pseudocoordination. In other words, we eliminated those examples that clearly named two separate, coordinated actions. We thus used the following "negative" cues for excluding what was not our construction:

\footnotetext{
${ }^{2}$ Figures for per million as given by Sketch Engine.
} 
- TAKE has its literal meaning, most clearly where it is modified by expressions such as 'carefully', 'into her hand', etc., which cannot relate to the action expressed by $\mathrm{V}$, or in the intensifying doubling of 'take and take (all the time)';

- The two actions may happen at different times and places and with different additional participants, most clearly where the adverbials of time or place relate only to either TAKE or the action expressed by $\mathrm{V}$, or in the combination of 'take and give';

- A fixed order, where the action of $\mathrm{V}$ follows an act of taking in a literal or metaphoric meaning (as opposed to combinations such as took and bought the car, where taking does not precede buying);

- Omitting TAKe changes the meaning or is odd;

- TAKE has arguments which are not shared by V such as a source (for example, took a book from the shelf and started reading);

- A shared participant has different semantic roles and is not a shared argument in the actual sentence (for example, took the knife and cut the bread);

- A shared participant is named twice, usually once as a full NP and the other time as a pronoun (took a cookie and ate it).

Note that the investigated languages are much freer in word order than English so that objects and adverbials do not need to-and often do not-appear in a place that would split the construction (for example, literally "took and ate a cookie", "from a shelf a book took and read").

Examples of the type took the cookie and ate it and took the knife and cut the bread could still be regarded as hendiadic in a broader sense (cf. Hopper 2002), but we decided to exclude them.

Evidently, during the process of filtering we also had to deal with instances whose status as pseudocoordination was not straightforward. The meaning of TAKE may be more or less literal, ${ }^{3}$ and the meaning of the whole may oscillate between referring to one complex action and two related actions. Such borderline instances occur mostly with transitive verbs as

\footnotetext{
${ }^{3}$ Cf. "If one looks at a large corpus of authentic examples with all their complexity, not making up a few simple ones, one perforce comes to the conclusion that 'lexical bleaching' must be regarded as a scalar variable, from maximally emptied, purely grammaticalised occurrences of take to less and less grammaticalized and more lexical ones." (Taube Ms, 25)
} 
$\mathrm{V}$ and a direct object which may be understood as a shared object of both verbs. The object may also be omitted, but be recoverable from a previous clause. Sometimes a larger context is needed to decide about the status of an example. Therefore, each example was carefully examined and the result is the best we could attain. Each language was examined by only one researcher and though we discussed the principles thoroughly, some of us might have been stricter in dealing with doubtful cases than others.

Another problem in data collection was observations that were doublets, repeated quotations, or almost verbatim repetitions. In the case of clear instances of repetition of the same utterance, the observation was included into the sample only once and its repetitions deleted. The same was done with repeated quotations that were marked by quotation marks.

Finally, we will briefly mention some variants that were not taken into consideration in this paper, but belong to its context and may be worth future studies. First, in some languages the verb for 'take' is also used with a reflexive marker. In Latvian, reflexive ņêmties has the meanings 'undertake, be ready to' and 'spend time doing, ponder over'. It usually combines with an infinitive but may also be used with a coordinated verb. In Polish, the use of the reflexive marker się in constructions with 'take' needs more thorough investigation - in our data, it was not always clear whether this marker belonged to the lexical verb, to 'take', or to the construction as a whole. Also Estonian kätte võtma may take a reflexive pronoun võtma ennast kätte, lit. 'take him/herself into hand'. The meaning is similar to kätte võtma in the construction and possible differences in meaning need more investigation.

Second, we did not consider prefixed forms of 'take' in the Baltic languages (Latvian pa-ņemt, Lithuanian pa-imti), which may occur in pseudocoordination similar to the respective simple verbs.

(3) Lithuanian

[5 Lt. kainavęs ir antra karta naudotas]

lietsargis per lietu pa-ime ir

umbrella.NOM.sG through rain.ACC.sG PVB-take.PST.3 and

pa-lūžo.

PVB-break.PST.3

'the umbrella [that cost 5 litas and was used for the second time] just broke during the rain'

However, this variant is by far less conventionalised and less frequent than the main variant. In Lithuanian, where the hendiadic construction 
with imti makes up $94 \%$ of a total of 1003 occurrences, with paimti only 77 of 118 occurrences (65\%) of the respective sequence qualified. In Latvian the number of raw observations was 1692 so that we refrained from manual filtering. A first look at the data however led us to assume that the situation is similar to Lithuanian with respect to the percentage of good examples, only the overall frequency is higher.

There is some interesting anecdotal evidence for the difference between Latvian ñemt un $\mathrm{V}$ and pa-ņemt un $\mathrm{V}$. In a much discussed political scandal in 2006, one of the involved persons was recorded with a Russian utterance that literally translates as "he took and deceived us". This was interpreted as 'he took [the bribe] and [after that, nevertheless] he deceived us' (in court, linguistic evidence played a crucial role: there was an audible pause after 'took'). This interpretation was rendered in Latvian with the prefixed verb: pan̄êma un uzmeta. The accused politician tried to defend himself, arguing that the person only said 'he deceived us' (thus, no evidence for the bribing), using the TAKE and V construction, which in this case was translated into Latvian with the simple verb: ņèma un uzmeta. Thus, Latvian media discussed whether the person had said 'ñēma un uzmeta' or 'pan̄ēma un uzmeta', and the variant with the prefix stood for the literal meaning of 'take'.

It would be worth investigating how far the construction with the prefixed verb has become an instance of pseudocoordination in Baltic and where it differs from the base construction with the simple verb, but this is beyond the present study. It is also interesting that in Baltic, the prefixed (in some sense "perfective") variant represents the construction less, while in Slavic the construction is much more conventional with the perfective verb. Estonian is similar to Slavic here, as the particle kätte has a perfectivising effect (see Section 4 ).

\section{The construction in Baltic - corpus findings}

Pseudocoordination with 'take' is well attested in contemporary Latvian and Lithuanian and shows a high degree of conventionalisation and cohesion. As shown in Table 1 in Section 2, the vast majority of occurrences of a string consisting of the lemma 'take', the coordinator 'and' and a lemma tagged as verb, represent the construction under investigation: $94 \%$ in Lithuanian (943 of 1003) and 83\% in Latvian (3093 of 3726). When counting only the most prominent verb forms, excluding participles and converbs, the percentage is still higher. In this section, we will present details concern- 
ing morphological, syntactic and semantic features of the constructions. If not mentioned otherwise, all Latvian examples in this section are taken from the corpus lvTenTen13, and all Lithuanian examples stem from the corpus LithuanianWaC_v2.

\subsection{Grammatical categories \\ Person, tense and mood}

The construction is attested with almost all forms of the Latvian and Lithuanian verbal paradigms, the only exceptions being some participles and converbs. Table 2 gives an overview of the attested forms in the two samples in absolute numbers and per hundred.

Table 2. Overview of inflectional forms in Latvian and Lithuanian

\begin{tabular}{|c|c|c|c|c|}
\hline Category & Lat. N & Lat. \% & Lith. \% & Lith. N \\
\hline Present (Latvian: including imperative) & 1242 & 40.2 & $24 \cdot 5$ & 231 \\
\hline Imperative (Lithuanian only) & - & - & 8.4 & 79 \\
\hline Past & 649 & 21.0 & 28.7 & 271 \\
\hline Past habitual (Lithuanian only) & - & - & 1.0 & 9 \\
\hline Future & 357 & 11.5 & 15.6 & 147 \\
\hline Irrealis & 75 & 2.4 & $5 \cdot 3$ & 50 \\
\hline Finite verb forms in sum & 2323 & 75.1 & 83.5 & 787 \\
\hline Infinitive & 618 & 20.0 & 15.6 & 147 \\
\hline Finite verb forms and infinitive in sum & 2941 & 95.1 & 99.0 & 934 \\
\hline Other forms & & & & \\
\hline Debitive (Latvian only) & 49 & 1.6 & - & - \\
\hline Evidential (Latvian only) & 6 & 0.2 & - & - \\
\hline Past Active Participle & 74 & 2.4 & 0.5 & 5 \\
\hline Past Passive Participle & 9 & 0.3 & 0 & o \\
\hline Present Active Participle & o & o & o & o \\
\hline Present Passive Participle & 3 & 0.1 & 0.3 & 3 \\
\hline Converb (Latvian -ot, Lithuanian - dam-) & 11 & 0.4 & 0.1 & 1 \\
\hline Sum of all verb forms & 3093 & $100 \%$ & $100 \%$ & 943 \\
\hline
\end{tabular}


As can be seen in the table, in both languages the construction most often occurs with verbs in a simple tense or mood form. Another frequent form is the infinitive, which itself most often depends on a verb in present or past tense (for example, a modal verb).

We will use our counts mainly for cross-linguistic comparison, here between Latvian and Lithuanian and in Section 6 among all our investigated languages. Still, a natural question is how within one language the distribution of forms in the investigated construction relates to the distribution of inflectional forms of verbs in general. Tables 3 and 4 oppose the figures for forms of 'take' within the construction (as in Table 2) and elsewhere ${ }^{4}$.

Table 3. Latvian ņemt 'take' within pseudocoordination (T\&V) and elsewhere (not T\&V)

\begin{tabular}{|c|c|c|c|c|}
\hline Category & $\mathrm{T} \& \mathrm{~V}$ & $\%$ & not $T \& V^{1)}$ & $\%$ \\
\hline Present/imperative & 1242 & $24 \cdot 5$ & 30580 & 25.2 \\
\hline Past & 649 & 21.0 & 11101 & 9.1 \\
\hline Future & 357 & 11.5 & 7144 & $5 \cdot 9$ \\
\hline Irrealis & 75 & 2.4 & 2296 & 1.9 \\
\hline Infinitive & 618 & 20.0 & 29017 & 23.9 \\
\hline other forms & 98 & $4 \cdot 9$ & 41408 & $34 \cdot 1$ \\
\hline total & 3039 & $100 \%$ & 121546 & $100 \%$ \\
\hline Finite verb forms in sum & 2323 & $75 \cdot 1$ & 51121 & 42.1 \\
\hline Finite verb forms and infinitive in sum & 2941 & 95.1 & 80138 & 65.9 \\
\hline
\end{tabular}

${ }^{1)}$ and not ņemt verrā 'take into account'

The comparison shows that pseudocoordination with ngemt 'take' indeed occurs more often with finite verbs than could be expected from the general distribution of forms of this word (the difference in "other forms", which comprise participles, converbs and the debitive, is highly significant). We

\footnotetext{
${ }^{4}$ For Latvian, we filtered out occurrences of the idiom ņemt vērā 'take into account, consider', which accounts for more than one third of the occurrences of nemt 'take'. As this idiom is used very often as a converb (ņemot vērā or vērā n,emot 'considering') or in passive voice, it would have skewed the statistics.
} 
also tested for significance in the differences without these "other forms", as they may somewhat distort the picture. The significance is still high ( $p$-value $<0.0001)$, and, as may be expected from the percentages given in Table 2, the greatest difference is in past tense, which is used significantly more often within pseudocoordination than elsewhere. However, Cramér's $\mathrm{V}$ is small (o.066), so the association between construction and inflectional form is not strong, which corresponds to our observation that pseudocoordination is compatible with different tense and mood categories.

Table 4. Lithuanian imti 'take' within pseudocoordination (T\&V) and elsewhere (not T\&V)

\begin{tabular}{l|l|l|l|l}
\hline \multicolumn{1}{c|}{ Category } & T\&V & $\%$ & not T\&V & $\%$ \\
\hline Present & 231 & $25 \%$ & 5554 & $25 \%$ \\
Imperative & 79 & $8 \%$ & 452 & $2 \%$ \\
Simple Past & 271 & $29 \%$ & 9232 & $42 \%$ \\
Habitual Past & 9 & $1 \%$ & 385 & $2 \%$ \\
Future & 147 & $16 \%$ & 1221 & $6 \%$ \\
Irrealis & 50 & $5 \%$ & 425 & $2 \%$ \\
Infinitive & 147 & $16 \%$ & 1667 & $8 \%$ \\
other forms & 9 & $1 \%$ & 3207 & $15 \%$ \\
$\quad$ total & $\mathbf{9 4 3}$ & $\mathbf{1 0 0 \%}$ & $\mathbf{2 2 1 4 3}$ & $\mathbf{1 0 0 \%}$ \\
Finite verb forms in sum & 787 & $84 \%$ & 17269 & $78 \%$ \\
$\quad$ Finite verb forms & 934 & $99 \%$ & 18936 & $85 \%$
\end{tabular}

The results obtained for Lithuanian data also show that finite verbal forms are found more often than non-finite ones in the construction than in the overall usage of the verb 'take'. The difference is statistically significant ( $p$-value $<0.0001$ ), even though the effect size is quite small (Cramér's $V=$ o.026). However, different from Latvian, Lithuanian favors infinitive forms in the construction (they appear twice more often than with the verb imti outside of the construction). Out of the finite forms, Lithuanian shows higher numbers for future tense and imperatives and lower numbers of the past tense in the construction than outside of it. 
Within the construction, the distribution of tense and mood forms is similar in both languages. A difference can be seen in the relative importance of present and past tense, especially in third person: in Latvian, third person present tense has a share of $24.3 \%$ of all forms $(\mathrm{N}=751$ of 3093$)$ and third person past tense one of $13 \%(\mathrm{~N}=401)$, in Lithuanian the respective figures are $19.4 \%$ for $3 . P R S(N=183$ of 943$)$ and $21.6 \%$ for $3 . P S T ~(N=204)$. The following tables show the distribution of person forms in tense forms and the imperative.

Table 5. Personal forms in Latvian (all forms = 3093)

\begin{tabular}{l|l|l|l|l|l}
\hline & $\begin{array}{c}\text { PRESENT/ } \\
\text { IMPERATIVE }\end{array}$ & PAST & FUTURE & Total & \% of all forms \\
\hline SSG & 75 & 209 & 62 & 346 & $11.2 \%$ \\
2 SG & 281 & 11 & 11 & 303 & $9.8 \%$ \\
3 SG/PL & 751 & 401 & 225 & 1377 & $44.5 \%$ \\
1 PL & 43 & 25 & 56 & 124 & $4.0 \%$ \\
2PL & 92 & 3 & 3 & 98 & $3.2 \%$ \\
SUm & $\mathbf{1 2 4 2}$ & $\mathbf{6 4 9}$ & 357 & $\mathbf{2 2 4 8}$ & $72.7 \%$
\end{tabular}

Table 6. Personal forms in Lithuanian (all forms =943)

\begin{tabular}{l|l|l|l|l|l|l|l}
\hline & PRS & IMP & PST & PST.HAB & FUT & Total & $\%$ of all forms \\
\hline ISG & 12 & - & 61 & 1 & 21 & 95 & $10.1 \%$ \\
2SG & 31 & 48 & 3 & 0 & 5 & 87 & $9.2 \%$ \\
3 SG/PL & 183 & - & 204 & 8 & 118 & 513 & $54.4 \%$ \\
1PL & 4 & 16 & 2 & 0 & 1 & 23 & $2.4 \%$ \\
2PL & 1 & 15 & 1 & 0 & 2 & 19 & $2.0 \%$ \\
Sum & 231 & 79 & 271 & 9 & 147 & 737 & $78.1 \%$
\end{tabular}

The role of the imperative can only be determined for Lithuanian, which has special forms for this mood. For $2 \mathrm{PL}$ and $1 \mathrm{PL}$, the imperative is the most important tense/mood form, but the overall frequency of these forms is low. For 2SG, the imperative makes up only slightly more than half of the forms (48 of 87 ). This is more than within all occurrences of 
the verb imti in the corpus, where the imperative accounts for $37.0 \%(\mathrm{~N}=$ 264) of 2 SG forms $(\mathrm{N}=715)$, and the most frequent form is present tense (2SG.PRS $=327$ or $45.7 \%$ of 715 ).

In Latvian, there is no morphological difference between 2SG imperative and present tense. A special imperative form exists only for 2PL (nemiet 'take!' vs present indicative n,emat 'you (PL) take, are taking'), but the distinction is often not made in unmonitored speech and writing, where both forms appear in both functions, and this is what we often find in our sample. For $1 \mathrm{PL}$, the future form is used in hortative meaning (nemsim 'we will take' or 'let's take!'), which may explain the relatively high number of occurrences of future for $1 \mathrm{PL}$ in Latvian as compared to the other persons and compared to Lithuanian.

We conclude that in the Baltic languages, the imperative is not especially prominent for the construction: past, present and future tense forms as well as the infinitive are more typical. However, if we look at the percentage of the imperative forms of 'take' outside of the construction, the percentage of the imperative within the construction is a few times higher.

Non-finite forms apart from the infinitive are relatively rare, especially in Lithuanian. However, the fact that the construction can be used in almost any form shows its firm place in the language and its general meaning. It is found in the passive (4) and in converb constructions (5), (6).

(4) Latvian: passive

$\begin{array}{llll}\text { Notikums } & \text { ñemts } & \text { un notušèts. } \\ \text { event.NOM.sG } & \text { take.PST.PP.NOM.SG.M } & \text { and } & \text { hush_up.PST.PP.NOM.SG.M }\end{array}$
'The event [was/has been] hushed up.'

(5) Latvian: converb construction

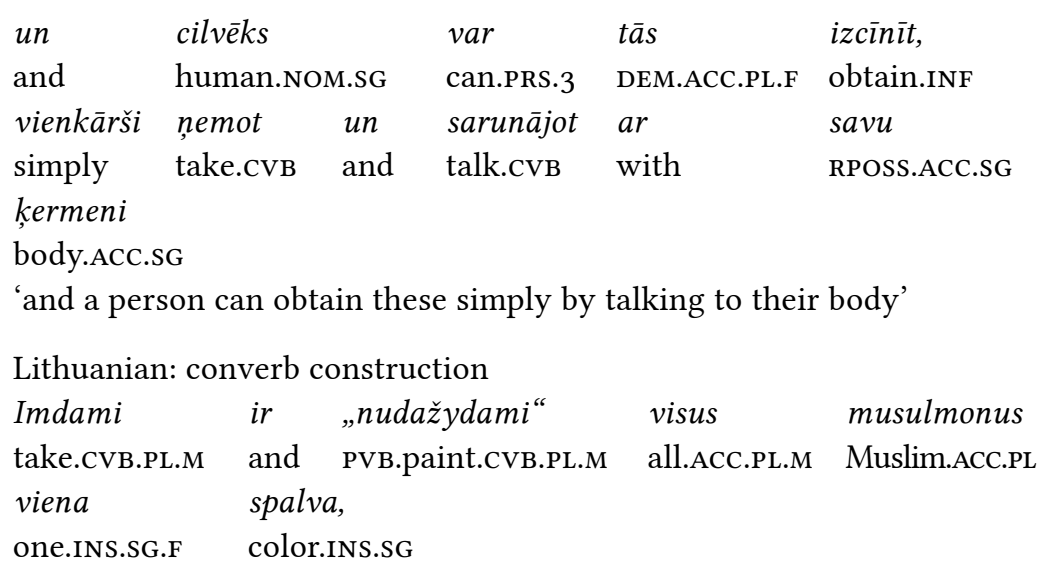


[mes paprasčiausiai užmirštame 600 metu islamo istorija Lietuvoje.]

'By “painting” all Muslims in one color, [we simply forget 600 years of history of Islam in Lithuania.]'

\section{Negation}

There are two possible ways to use the hendiadic construction with negation. The more common one is to use the negative prefix only with the second verb (29 observations in Latvian and 27 observations in Lithuanian in the samples). Semantically as well as formally, only the second verb is under the scope of negation, while the abstract meaning of TAKE is retained. The negated action is treated as an event or activity - for example, (7) can be paraphrased as 'what happened was that the teacher didn't show up', and (8) as 'what you have to do is not-smoke'.

(7) Latvian: negation with TAKE and NEG-V

Pasniedzēja ñèma un neieradās uz eksāmenu!
teacher.NOM.sG take.PST.3 and NEG.appear.PST.3 to exam.ACC.SG
'The teacher did not turn up at the exam!' (unexpectedly, untypically)

(8) Latvian

[Nekas nav vieglak ka atmest smēḳēšanu. nav vajadzīgas ne filmas, ne grāmatas, ne hipnotiskie diski!]

Vienkārši ņem un nesmēķē.

simply take.PRS.2SG and NEG.smoke.PRS.2SG

'[Nothing is easier than to give up smoking. You don't need films, nor books, nor hypnotic discs!] Just don't smoke.' (without any preparation, just like that)

(9) Lithuanian

$\begin{array}{lllll}\text { Negalejau } & b \bar{u} t i & \text { tikra, } & k a d & \text { Edvardas } \\ \text { NEG.can.PST.1SG } & \text { be.INF } & \text { sure.NOM.SG.F that Edvardas.NOM.SG } \\ \text { vel ims } & \text { ir } & \text { neišnyks. } & \\ \text { again take.FUT.3 and } & \text { NEG.PVB.disappear.FUT.3 } \\ \text { 'I couldn't be sure that Edvardas would not [suddenly] disappear again.' }\end{array}$

The second possibility is to formally negate both verbs. In the Latvian corpus there were 11 clear instances, of which 7 were in future tense; in the Lithuanian corpus we found 6, with 3 of them in future tense. ${ }^{5}$ The scope of

\footnotetext{
${ }^{5}$ These examples are not part of the sample. A verb with negative prefix is tagged as a different lexeme, thus the initial query did not cover these constructions.
} 
the negation is over the whole construction, that is, meaning components such as 'suddenly', 'unexpectedly', 'without preparation' are also negated. The utterance refers to an event that does not or will not happen.

(10) Latvian: negation with NEG-TAKE and NEG-V

\begin{tabular}{|c|c|c|c|}
\hline vienkārši & noteikti & neñems & un \\
\hline simply & certainly & NEG.take.FUT(3) & and \\
\hline neanulēs & atļauju, & bet vērtēs & füsu \\
\hline $\begin{array}{l}\text { NEG.cancel.FUT(3) } \\
\text { situāciju. }\end{array}$ & permit.ACC.sG & $G$ but assess.FuT(3) & 2PL.GEN \\
\hline
\end{tabular}

'They certainly won't cancel [your] permit just like that, but will assess your situation.'

(11) Lithuanian

\begin{tabular}{lllll} 
Juk kiekvienas & \multicolumn{2}{c}{ žaidejas } & neims & ir \\
PTC every.NOM.SG.M & player.NOM.SG.M & NEG.take.FUT.3 and \\
neskaitys & triju & kandidatu & laikrasčiu. \\
NEG.read.FUT.3 three.GEN.PL & candidate.GEN.PL & newspaper.GEN.PL \\
'Every player will not (suddenly, without good reason) read the news- \\
papers of three candidates.'
\end{tabular}

The meaning of the two patterns of negation may be described by the following formulas:

Pattern 1: TAKE and [NEG V]

Pattern 2: NEG [TAKE and V]

Note that the abstract meanings of TAKE cannot be negated alone, only within the whole construction. That is, we don't find a third pattern * $[$ NEG TAKE] and V.

\subsection{Cohesion and the place of arguments and adjuncts}

In Baltic, the construction TAKE and V shows a high degree of cohesion. The construction most commonly consists of exactly these three elements without interrupting words, and the order of the elements is fixed. Arguments and adverbs are usually placed before or after the construction, as can be seen in many of the examples given in this section. We will now explore the range of deviation from this most typical situation. First, we consider variants of the construction without the coordinator 'and'. Second, we explore the possibility of placing arguments, adverbs and particles 
within the construction. The observations discussed in this section were obtained by additional queries.

\section{Presence vs absence of 'and'}

The asyndetic type TAKE (,) V is not frequent in contemporary Latvian and Lithuanian as reflected in the corpora we used.

In Lithuanian, we found 9 examples of an asyndetic construction, as opposed to 943 examples with 'and'. Asyndetic examples occur with and without a comma between the two verbs.

(12) Lithuanian

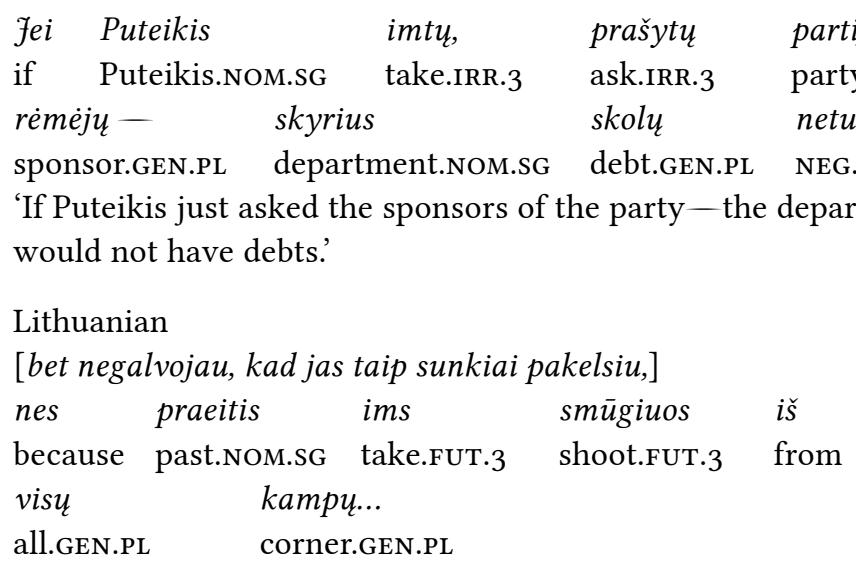

'[But I didn't think that I would take it so badly,] because the past would suddenly hit from all corners...'

The situation is the same in Latvian. Corpus examples of the type without comma often do not feel really natural; the word 'and' may simply be omitted by mistake. A query searching for NeMT V in the past tense got 24 hits, of which only 11 were qualified ( 8 in third person, $1=2$ SG and $2=1 \mathrm{SG}$ ). Asyndetic pseudocoordination with a functional imperative of 2SG tense was found a bit more often: 12 times without comma (n,em V!) and 19 times with a comma (nem, V!). Still, these figures are significantly lower than those for imperatives in pseudocoordination with a coordinator.

We conclude that the asyndetic type is very rare in contemporary Baltic, and does not seem to evolve into a double verb construction as in Russian.

Another subtype of the construction allows asyndetic coordination between 'take' and V, with one or more additional verbs and 'and' before the last of these verbs. 
(14) Lithuanian

Grįši i pamoka? - Gal juokauji?

'Will you come back to class? - Are you kidding?'

$\begin{array}{lll}\text { Taip } & \text { jau imsiu, } & \text { apsisuksiu } \\ \text { this.way } & \text { PTC take.FUT.1SG } & \text { PVB.RFL.turn.FUT.1SG } \\ \text { ir } & \text { grišiu. } & \\ \text { and } & \text { return.FUT.1SG } & \end{array}$

'So I just suddenly turn around and come back.'

(15) Latvian

$\begin{array}{lllll}\text { ja nu } & \text { beidzot } & \text { ņem, } & \text { sadusmojas } & \text { un } \\ \text { if PTC } & \text { finally } & \text { take.PRS.3 } & \text { get.angry.PRS.3.RFL } & \text { and } \\ \text { patiesi } & s \bar{a} k & \text { šaut? } & & \\ \text { really } & \text { start.PRs.3 } & \text { shoot.INF } & \\ \text { 'what if they finally get angry and start to shoot for real?' } & \end{array}$

In this subtype the last verb often denotes a result, as in the two previous examples. Another use of the construction is with several verbs that have a similar meaning, where the accumulation is used for emphasis.

(16) Latvian

\begin{tabular}{|c|c|c|c|}
\hline $\begin{array}{l}\text { tevi, } \\
\text { 2SG.ACC }\end{array}$ & $\begin{array}{l}\text { nabadzìti, } \\
\text { poor_one.ACC.sc }\end{array}$ & & $\begin{array}{l}n, \bar{e} m a, \\
\text { take.PST.3 }\end{array}$ \\
\hline piemānīja, & izmantoja & un & maldināja? \\
\hline ude.PST.3 & use.PST.3 & and & mislead.PST.3 \\
\hline
\end{tabular}

These examples show that TAKE may have scope over more than one verb.

\section{Placement of arguments, adverbs and particles}

If elements are inserted into the construction, they most often are single words. More complex phrases are possible, but rare. As a rule, a noun phrase immediately following TAKE is an argument of this verb and the sequence does not represent the hendiadic construction (for example, combinations of the type take a book and read). We found only a few exceptions to this rule in the Lithuanian and Latvian corpora. We suspect that the possibility of inserting an argument of the hendiadic construction in this slot is higher for arguments consisting of a single word (noun, pronoun or numeral). Subjects seem to be more acceptable than other arguments. In Lithuanian, we found in this position 14 subjects and 10 objects. 
(17) Lithuanian: subject after TAKE

$\begin{array}{lllll}O & \text { dabar } & \text { isivaizduok, } & & \\ \text { and } & \text { now } & \text { imagine.IMP.2SG } & & \\ \text { kad } & \text { ima } & \text { Rusija } & \text { ir } & \text { pradingsta } \\ \text { that } & \text { take.PRS.3 } & \text { Russia.NOM.SG } & \text { and } & \text { PVB.disappear.PRs.3 }\end{array}$

(18) Latvian: subject after TAKE

[Nu neizklausās jau tīri ticami ...]

$\begin{array}{llll}\text { ñēma } & \text { krievi } & \text { un nogremdēja } & \text { to } \\ \text { take.PST.3 } & \text { Russian.NOM.PL } & \text { and sink.CAUS.PST.3 DEM.ACC.SG } \\ \text { nabaga } & \text { kuteri } & \text { citiem } & \text { kuteriem } \\ \text { poor } & \text { boat.ACC.SG } & \text { other.DAT.PL } & \text { boat.DAT.PL } \\ \text { par } & \text { biedinājumu ... } & & \\ \text { for } & \text { threat.ACC.SG } & \\ \text { ['Well, it doesn't sound really believable...] The Russians (just like } \\ \text { that) sank the poor boat as a threat to other boats...' }\end{array}$

Positioning the subject directly after 'take' puts emphasis on the meanings conveyed by 'take' in this construction, such as 'suddenly', 'unexpectedly', 'just like that'. The position after the second verb would be more neutral in this respect (paraphrasing the Lithuanian example: ima ir pradingsta Rusija); it would put the subject into focus ('Russia, of all countries').

Direct objects in this position were found only in Lithuanian. In 8 of 10 observations the object was a pronoun. In some examples such as (19), the object could be considered as shared between 'take' and the lexical verb, while in a few other observations the noun phrase cannot be considered an argument of 'take' (20).

(19) Lithuanian: object of TAKE and/or V

[nusprendè savu minčiu nebemarinuoti,]

o tiesiog imti jas ir igyvendinti...

but just take.INF 3.ACC.PL.F and PVB.bring.to.life.INF

' $[[\mathrm{He}]$ decided not to preserve his thoughts] but just bring them to

life' / 'take them and bring [them] to life'

(20) Lithuanian: object only of $\mathrm{V}$

[Kai žemé buvo išdalyta, pievu niekas nenušienavo, todèl dabartiniai savininkai tingédami dirbti, $]^{6}$

\footnotetext{
${ }^{6}$ Mistake in the corpus example corrected: dirbti instead of dirbi.
} 


$\begin{array}{llll}\text { ima } & \text { laukus } & \text { ir } & \text { padega } \\ \text { take.PRS.3 } & \text { field.ACC.PL } & \text { and } & \text { PVB.burn.PRs.3 }\end{array}$

'[When the land was divided, nobody took the hay from the fields, and that's why current owners, being lazy to work,] simply burn the fields' ("take the fields and burn")

In Latvian, a direct object directly after TAKE was always identified as an argument of 'take' in a literal or abstract sense, not as an argument of the hendiadic construction.

Adverbs and particles are a bit more frequent than arguments in the slot immediately after TAKE. What we find here are words with a meaning that corresponds to the meaning conveyed by the construction, such as 'suddenly', 'simply', 'just', 'unexpectedly', 'however', 'yet'.

(21) Lithuanian: 'suddenly' inserted after 'take'

fuk tikisi, kad mama kaipnors ims

PTC hope.PRS.3.RFL that mom.NOM.SG somehow take.FUT(3) staiga ir išmoks anglu kalba. suddenly and PvB.learn.Fut(3) English.GEN.PL language.ACc.sG 'He hopes his mom will somehow suddenly learn English.'

These words may also appear in the following slot.

(21) Lithuanian: 'suddenly' inserted before $\mathrm{V}$

$\begin{array}{lccc}\begin{array}{l}\text { eme } \\ \text { take.PST.3 }\end{array} \text { and } & \text { staiga } & \text { išgaravo } & \text { visas } \\ \text { gražus } & \text { suddenly } & \text { PVB.disappear.PST.3 all.NOM.SG.M } \\ \text { vaizdelis } & \text { ir } & \text { mano } \\ \text { beautiful.NOM.SG.M } & \text { view.DIM.NOM.SG and } & \text { my } \\ \text { susikurtas } & \text { romantizmas... } \\ \text { create.PST.PP.NOM.SG.M } & \text { romanticism.NOM.SG } \\ \text { 'suddenly the whole beautiful vision and the romanticism created by } \\ \text { me disappeared...' }\end{array}$

These words are in general collocates of the construction, that is, they are often found in its vicinity (see below Section 3.3). Latvian adverbs and particles in question include vienkārši 'simply; just', tā 'just (so)', tikai 'only', taču 'however, yet', pēkšn,i 'suddenly', vēl 'still', tik 'hardly, barely' and a few others. Most of these items appear only 1-3 times in one of the positions within the construction. Only two of these words have a more significant number of occurrences: $v \bar{e} l$ 'still' was found 21 times in the first slot and 11 times in the second slot, and for tik 'hardly, barely' the respective figures are 19 and 9. It is worth noting that these two words have 
little semantic meaning and are rather pragmatic particles. The particle tik appears in the first slot most often with a functional imperative (14 of 19 observations), and the construction may be used as a kind of formula, not directed to a particular addressee.

(23) Latvian: particle tik after 'take'

$\begin{array}{lllll}\text { Tãds } & \text { rutinas } & \text { darbs, } & \text { ņem } & \text { tik } \\ \text { such.NOM.SG.M } & \text { routine.GEN.SG } & \text { work.NOM.SG } & \text { take.PRS.2SG } & \text { PTC } \\ \text { un } & \text { mezglo. } & & & \\ \text { and } & \text { knot.PRS.2SG } & & & \end{array}$

'It's routine work, [you] just make knots.'

The other more frequent particle, $v \bar{e} l$, appears mostly with the verbs in future tense (20 of 21 observations) and expresses a kind of negative stance, a fear that something might happen as a consequence of another action or situation. Latvian $v \bar{e} l$ shares many of the meanings of the German word noch, which would be natural in translations of these examples. There is no English translation equivalent. ${ }^{7}$

(24) Latvian: particle vēl after 'take'

$\begin{array}{llll}\text { Sak, } & \text { uzmanies } & \text { ko } & \text { padoma } \\ \text { PTC } & \text { beware.PRS.2SG.RFL } & \text { what.ACC think.PRS.2SG } \\ \text { ņems } & \text { ve l } & \text { un } & \text { piepildisies! } \\ \text { take.FUT.3 } & \text { PTC } & \text { and } & \text { become.true.FUT.3.RFL } \\ \text { 'As they say: beware what you think, it might come true!' } \\ \text { (German: 'Nach dem Motto: pass auf, was du denkst, es wird [sonst] } \\ \text { noch wahr!') }\end{array}$

Both these particles may also appear in the following slot, between the coordinator and the lexical verb.

(25) Latvian: particle $v \bar{e} l$ after 'and'

\begin{tabular}{|c|c|c|c|}
\hline $\begin{array}{l}\text { n,emsi } \\
\text { take.FUT.2SG }\end{array}$ & $\begin{array}{ll}\text { un } & v \bar{e} l \\
\text { and } & \text { PTC }\end{array}$ & $\begin{array}{l}\text { pats } \\
\text { self.NOM.SG.M }\end{array}$ & $\begin{array}{l}\text { noticēsi } \\
\text { believe FUT 2SG }\end{array}$ \\
\hline tam & & runā & \\
\hline DEM.DAT.SG.M & what.ACC & talk.PRS.2SG & \\
\hline
\end{tabular}

\footnotetext{
7 The Lithuanian equivalent is dar, which also often occurs in sentences containing our construction; see (35) for an example.
} 
In this example we also see the emphatic pronoun pats 'self' in the slot between 'and' and V, which shows that a certain distance between 'take' and the main verb $\mathrm{V}$ is allowed without the constructional meaning being at stake.

In general, arguments and manner adverbs in the second slot relate to the following verb, while other adverbs and particles may relate to the whole construction. In (26), the pronoun vinga 's/he.Loc' (here: 'with her') is a complement of iemīlēties 'fall in love', and sasodìti 'damned', here 'madly', is a manner adverb modifying this verb. In (27) kaut ko 'something' is a complement of the verb izdarit 'do', while vienreiz 'once' modifies the whole construction. Note also the different order of adverb and argument in the two examples.

(26) Latvian: argument and manner adverb before $\mathrm{V}$

[un tas man nav traucējis]

ņemt un viñā sasodīti iemīlēties

take.INF and 3SG.LOC damned.ADV fall_in_love.INF.RFL

'[and that hasn't prevented me] from falling madly in love with her'

(27) Latvian: temporal adverb and argument before $\mathrm{V}$

Tad ñem un vienreiz kaut ko
then take.PRs.2SG and once
$\begin{aligned} & \text { izdari, } \\ & \text { something.ACC }\end{aligned}$
PVB.do.PRs.2SG NEG.chirp.PRs.2SG
'Then go ahead and do something for once, don't whimper.'

As can be seen in the examples, the slot between the coordinator and the lexical verb allows the insertion of more than one constituent. Furthermore, elements in this slot may be complex (as in 29), though one-word constituents are much more common.

(28) Lithuanian: simple argument (pronoun) before $\mathrm{V}$

organizatoriai paskutiniu momentu

organiser.NOM.PL last.INS.SG.M moment.INS.SG

ima ir viska atšaukia.

take.PRS.3 and everything.ACC PVB.call.PRs.3

'at the very last moment the organisers call everything off.'

(29) Lithuanian: prepositional phrase with complex noun phrase before $\mathrm{V}$

jie ime ir su virvute,

3.NOM.PL take.PST.3 and with rope.DIM.INS.SG

prakiše pro kelniu kišenę

PVB.put.PA.PST.NOM.PL through pants.GEN.PL pocket.ACC.SG 


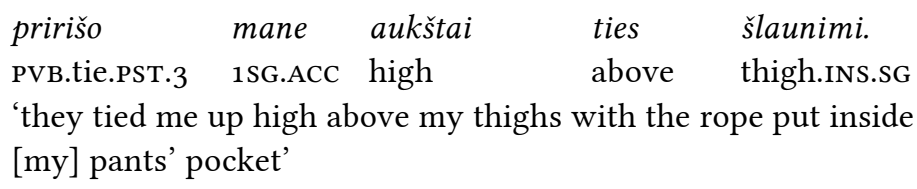

While the appearance of arguments and adverbials in the slot directly before the main verb is by no means exceptional, it is still much less common than the placement of such elements before or after the string "TAKE and V".

\subsection{Lexical variation and semantics of arguments}

The construction is found with almost all semantic and formal types of verbs and with all kinds of subjects. In this section we will discuss preferences for certain classes.

\section{Simple and prefixed verbs; event types and boundedness}

Prefixed verbs are more often used in the construction than simple verbs. There are slight differences between the two languages (in Lithuanian the percentage of prefixed verbs is higher) and between individual verb forms. In both languages the percentage of prefixed verbs is higher in past tense than in present tense; in Lithuanian also future forms are overwhelmingly found with prefixed verbs. Table 7 shows the differences between the languages and between the three simple tenses for third person forms. ${ }^{8}$

Table 7. Percentage of prefixed lexical verbs in third person forms of the construction

\begin{tabular}{l|l|l|llll|l}
\hline & \multicolumn{3}{|c}{ Lithuanian } & & \multicolumn{3}{c}{ Latvian } \\
\cline { 2 - 4 } \cline { 5 - 7 } present & with PFX & total & \% PFX & & with PFX & total & $\%$ PFX \\
\cline { 2 - 8 } & 155 & 183 & 84.7 & & 546 & 751 & 72.70 \\
past & 186 & 204 & 91.18 & & 354 & 401 & 88.28 \\
future & 109 & 118 & 92.37 & & 169 & 225 & 75.11
\end{tabular}

\footnotetext{
${ }^{8}$ Unfortunately, we do not have comparable numbers for the occurrence of prefixed and non-prefixed verbs outside of the construction, but the percentage of prefixed verbs in pseudocoordination seems to be high in any case.
} 
The lowest percentage of prefixed verbs was found in 2SG present tense and imperative. In Latvian, only $47.8 \%$ of these forms have a prefix in the construction ( $\mathrm{N}=131$ of 274$)$. In Lithuanian, 2SG.IMP has the lowest number of prefixed verbs, namely $44 \%(\mathrm{~N}=21$ of 48$)$, as opposed to 2PL.IMP which has $80 \%$ of prefixed verbs $(\mathrm{N}=12$ of 15$)$. The percentage of prefixed verbs is also relatively low in the present tense (especially 1 SG.PRS, $58 \%$ of prefixed verbs, or $\mathrm{N}=7$ of 12 ), as opposed to the simple past where the percentage of prefixed verbs is $91 \%$ (in 3.PST, $\mathrm{N}=183$ of 204) or higher.

The preference for prefixed verbs relates to a preference for verbs that include an inner boundary. If a root denotes an unbounded activity or state, the prefix either highlights its beginning (ingressive, inchoative verbs), or otherwise delimits its duration. For example, instead of Latvian gribēt 'want' we find the verb sagribēt, whose meaning is described as 'suddenly begin to want, wish' in the Latvian dictionary LLVV.

(30) Latvian: prefix indicating the beginning of a state [Bet vienalga-tā pirmkārt ir jūsu izvēle. Tieši jūs gribējāt dzīvot tādu dzìvi. Apzinieties to!]

$\begin{array}{lll}\text { Un tagad nemiet } & \text { un sagribiet } \\ \text { and now } & \text { take.IMP.2PL } & \text { and PVB-want.IMP.2PL } \\ \text { izmainit } & \text { savu } & d z \bar{\imath} \text { vi! } \\ \text { PVB. change.INF } & \text { RPOSS.ACC.SG } & \text { life.ACC.SG }\end{array}$

'But anyhow - first of all it is your choice. It is you who wanted such a life. Be conscious of it! And now start wanting to change your live!'

The next example shows a prefix with delimitative function: pie-sēst 'sit down, usually for a short time' (translated from LLVV), opposed to unprefixed sēsties 'sit down'. The meaning 'for a short time' is additionally spelled out by the adverbial $u z$ brìdi 'for a moment'. The following two verbs also have delimitative prefixes: ie-dzert 'drink (a certain amount)', pa-plāāāt 'chat (a little bit, for a while)'.

(31) Latvian: prefix delimiting the state resulting from an activity N̦ēmām un pie-sēdām uz brīdi, take.PST.1PL and PVB-sit_down.PsT.1PL for moment.ACC.SG ie-dzērām mazliet kafijas un pa-plāāājām. PVB-drink.PST.1PL a_little coffee.GEN.SG and PVB-chat.PST.1PL 'We sat down for a while, had some coffee and chatted a bit.'

However, unbounded processes and states also occur. This may be more acceptable in Latvian than in Lithuanian, but Lithuanian utterances 
with verbs like 'believe', 'sleep, be asleep', 'rain, be raining' were found in spontaneous, colloquial writing on the Internet, and were accepted and judged natural by native speakers.

(32) Latvian: unbounded state ('believe')

Iemesls, kādèl es to gribētu lasìt, ir tas, ka es ticu Dombrovskim.

Tā vienkārši n,emu un ticu

so simply take.PRs.1SG and believe.PRs.1SG

'The reason why I would like to read it is that I believe Dombrovski.

I simply believe [him].' (The context made it clear that nemu 'I take' here does not refer to taking the book)

In general, all kinds of event types (Vendler's classes) are found with the construction, but activities and accomplishments are more common than achievements and states.

\section{Transitive and intransitive verbs and prominent exemplars}

Transitive verbs are more common in the construction than intransitive verbs, but the latter are well attested. With intransitive verbs, the construction appears more clearly, that is, the abstract meaning of TAKE is indisputable, while with transitive verbs TAKE often retains some of its lexical meaning. Thus, numbers of types and tokens of intransitive verbs may be an indicator of the grammaticalisation of the construction.

Among intransitive verbs, the following semantic classes of verbs are especially well attested in Latvian and Lithuanian:

- Movement, especially voluntary, directed movement ('go/run/ drive away', 'come running/by transport', 'go/drive somewhere')

- involuntary change of state, including:

- 'die' - apart from the basic lexeme for 'die', we find various more specific verbs with meanings such as 'drown', 'freeze to death', 'suffocate', etc.;

- 'break', 'go to pieces';

- various other verbs denoting a change of state, for example, 'fall asleep', 'fall in love', 'faint', 'disappear', 'wither', 'turn sour' (of milk etc.).

Verbs denoting a change of state are often found with inanimate subjects. 
As a reviewer pointed out, it is interesting that the two prominent classes of intransitive verbs found in the construction are opposite with respect to volitionality. This points to a shift instead of a continuum. As we will suggest below, with the second class (involuntary change of state), the construction gets a new prototype and the meaning of unexpectedness comes to the fore.

\section{Animacy and volition; semantic roles of subjects}

The construction is used with all kinds of subjects and may refer to involuntary, unconscious, accidental actions and processes. There are many examples with an inanimate subject, often concrete ones such as cars, machines, but also abstract ones such as ideas, incidents.

(33) Lithuanian: inanimate concrete subject, change of state miestas ir tapo didžiausiu

city.NOM.SG take.PST.3 and become.PST.3 largest.INS.SG.M

visoj Nevadoj

all.LOc.sG.F Nevada.LOc.sG

'all of a sudden the city became the largest in the whole [state of] Nevada'

(34) Lithuanian: inanimate abstract subject ('thoughts'), change of state

neduok Dieve, tos blogo

NEG.give.IMP.2SG God.voc.SG DEM.NOM.PL.F bad.NOM.PL.F

mintys dar ims ir materializuosis.

though.NOM.PL PTC take.FUT.3 and materialise.FUT.3.RFL

'God forbid those bad thoughts will materialise.'

The subject may also be semantically vague and does not have to be explicitly named.

(35) Latvian: inanimate abstract subject ('something new')

[Kaut gan mēs domājām, ka arī ar veco labo peli vairs nekas jauns nenotiks...]

bet ñema notika

but take.PsT.3 and happen.PsT.3

'Although we thought that nothing new would happen to the good old [computer] mouse... But [it] did.' ("[it] took and happened")

Also zero-valent weather verbs are attested.

9 The particle dar emphasises the meaning of 'God forbid'; cf. Latvian vēl discussed above with (24) and (25). 
(36) Latvian: weather verb

[Vien žēl, ka laika apstākḷi tā izbojājās. Turējās, turējās, bet nu,

kad patiesi vajadzētu salu,]

ņem un lìst.

take.PRs.3 and rain.PRs.3

'[Only a pity that the weather has turned bad. [The good weather] lasted, lasted, but now, when we really would need frost,] it is raining.'

With human subjects, the construction may refer to an action carried out involuntarily, unconsciously, or a process happening without conscious influence.

(37) Lithuanian: unconscious, unintentional action

Aš pati nesuvokdama kartais

1SG.NOM self.NOM.SG.F NEG.realise.cvB.SG.F sometimes

imdavau ir padarydavau kanors

take.PST.HAB.1SG and do.PST.HAB.1SG something.ACC

neiprasta...

unusual.N

'Sometimes I, not realising myself, would suddenly do something unusual...'

As mentioned above, a prominent group of verbs denoting involuntary actions/processes are verbs of dying.

(38) Lithuanian

\begin{tabular}{|c|c|c|c|}
\hline b & žiūrèk & koks & sveikuolis \\
\hline and & look.2SG.IMP & what.NOM.SG.M & healthy_person.NOM.sG \\
\hline & ir & pasimirè & 6o-ties. \\
\hline ST. 3 & and & PVB.RFL.die.PST. 3 & sixty.GEN.SG \\
\hline
\end{tabular}

'And look what a healthy person suddenly died [being] 6o years old'

All semantic roles are attested for subjects. Agents as subjects of transitive and intransitive verbs and patients as subjects of intransitive verbs have been shown in many of the above examples. Recipients are rare, but attested - which shows the total bleaching of the meaning 'take'.

(39) Latvian: recipient subject

$\begin{array}{llll}\begin{array}{l}\text { bet viņš } \\ \text { but }\end{array} \text { 3SG.NOM.M } & \begin{array}{l}\text { take.PST.3 and } \\ \text { galveno }\end{array} & \text { balvu } & \text { dabūja } \\ \text { get.PST.3 } & \\ \text { main.ACC.SG.DEF } & \text { award.ACC.SG } \\ \text { 'but he got the main award (unexpectedly)' }\end{array}$


The occurrence of experiencers may be in some way restricted, which needs further investigation. For example, in our corpora there are no examples of the use of uncontrolled sensory experience in the construction (with verbs such as 'see', 'hear'). Another verb which seems to be impossible to use in the construction is 'know'. This may be related to volitionality rather than aspectuality, as 'believe' is attested (assuming that it is easier to influence one's belief by will than one's knowledge). Emotions and bodily sensations are often expressed in Baltic in a construction where the experiencer is in the dative and thus cannot be coordinated with the nominative subject of 'take'. With such verbs, it is the stimulus that is the subject of the construction.

(40) Latvian: stimulus subject

Un skaties tās Tev nem

and look.PRS.2SG.RFL DEM.NOM.PL.F 2SG.DAT take.PRS.3

un iepatìkas.

and please.Prs.3.RFL

'And look, you suddenly like them (= the slippers)'

(constructed as 'they please you')

\subsection{The meaning(s) of the construction}

We found the construction with the same range of meanings in Latvian and Lithuanian. For the sake of brevity, we will concentrate here on Latvian.

It is not easy to name a core meaning of the TAKE (and) V construction, as several factors influence the reading of a particular occurrence of the construction. In monolingual Latvian dictionaries the construction is defined in different ways. In the largest dictionary, LLVV (Vol. 6, 1986) the meaning is described as intensifying the action expressed by the lexical verb, while the one-volume dictionary LVv (1987) also ascribes an inchoative component to the construction ('suddenly start and carry out straight away, definitely'). As already stated by Ivulāne (2015), both definitions fit only a part of the attested uses of the construction. Ivulāne $(2015,144)$ draws the following conclusion from her discussion of various examples from corpora and Internet sources:

"Tātad iespējamās nozīmes, kuras ņemt piešķir konstrukcijai, ir pabeigtība [...], darbības pēkšn,ums, apṇēmība, uzdrošināšanās, nejaušība, pamatojuma trūkums, iespējams, vēl kādas." (emphasis added) 
"Thus the possible meanings that ņemt bestows upon the construction are completeness [...], suddenness of the action, resoluteness, daring, haphazardness, lack of reason, and maybe others."

We agree with Ivulāne that the construction does not have one (invariant) meaning, but may convey various meanings, which may even be contradictory (such as 'resoluteness' and 'haphazardness'). Morphological categories and the communicative function (purpose) of an utterance influence the interpretation of an individual instance of the construction. Thus, ņēma un nomira 'took and died' (unintentional change of state, past tense third person, narrative) gets interpreted as 'died suddenly, unexpectedly', while these meaning components do not arise in constructions such as ņem un izdari! 'take and do (it)!' (intentional action, present/imperative 2SG, persuasive), which is rather interpreted as 'go ahead, just do it'.

As the usage of the construction spreads from transitive to intransitive verbs, from volitional actions to uncontrolled processes, from activities to states, it develops a more and more abstract base meaning, or rather a pragmatic function. This general function of the construction is to put the action, process or state expressed by the lexical verb into focus, in a way by "pointing to it". The English idiomatic expression (just) like that conveys meanings similar to that of the TAKE and V construction in Latvian, and its etymology is clearly related to "pointing at" something.

By laying the focus on the action or process itself, the speaker abstracts from any preparations for it, which invites the meaning components 'spontaneously, by itself', 'suddenly' and 'unexpectedly'. These meanings are often additionally expressed by co-occurring words such as pēkšni 'suddenly', vienkārši 'simply, just', tā 'so, just', or more elaborate expressions such as ne no šă, ne no tā 'without reason'.

(41) Latvian: 'without preparation', 'without warning' - 'without (apparent) reason'; patientive verb, change of state

\begin{tabular}{|c|c|c|c|c|}
\hline Braucot, & no & $\check{s} \bar{a}$ & no & \\
\hline drive.cvB & from & DEM.GEN.SG.M & NEG from & DEM.GEN.SG.M \\
\hline mašina & ņem & un & noslāpst. & \\
\hline car.NOM.SG & take.PRS.3 & and & conk_out.PRS. & \\
\hline
\end{tabular}

A spontaneous and unexpected change of state seems to be more noteworthy if it is also unwanted. The majority of constructions with an 
inanimate subject and a sudden change of state in Latvian and Lithuanian report about an unpleasant process or result: machines breaking down, objects falling to pieces, documents suddenly disappearing, rain spoiling weekend plans. Thus, the construction gets associated with something negative - but only with involuntary changes of state or with states, not with voluntary actions by humans, and probably also not with abstract subjects such as ideas or events, as constructions with these are often about something that is evaluated positively.

By explicitly pointing to an action or state, the speaker may also contrast it to others, carried out by the same or another actor. The meaning of contrast is further emphasised by the frequently co-occurring connectives and adverbs bet 'but', taču, tak or tomēr 'however, yet', kamēr 'while'.

(42) Latvian: 'in contrast (to action by other actor)'

\begin{tabular}{|c|c|c|c|c|}
\hline kamēer & es & runāju & & ņêma \\
\hline while & 1SG.NOM & talk.PST.1SG & 3.NOM.SG.F & take.PST \\
\hline $\begin{array}{l}\text { un } \\
\text { and }\end{array}$ & $\begin{array}{l}\text { lzaarlja } \\
\text { PvB.do.ps }\end{array}$ & & & \\
\hline
\end{tabular}

Often, there is a contrast: not one between two actions, but between an actual situation and the expectations of someone.

(43) Latvian: 'in contrast (to expectations)'

\begin{tabular}{|c|c|c|c|c|c|}
\hline & ve.PST.3 & $\begin{array}{l}\text { nedomāja } \\
\text { NEG.think.PST.3 }\end{array}$ & $\begin{array}{l}\text { elite, } \\
\text { elite.NOM.SG }\end{array}$ & $\begin{array}{l}k a \\
\text { that }\end{array}$ & \\
\hline 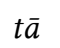 & nems & $\omega$ & sabruks & & \\
\hline $\mathrm{TC}$ & take.FUT.3 & and & fall_to_piece & 3 & \\
\hline
\end{tabular}

'The elite did not believe, they did not think that the UssR would just fall to pieces'

Thus, the meaning of unexpectedness, which we find so often with this construction, is maintained from two sources: the meaning components 'without preparation or warning' and 'in contrast'. Furthermore, when the main function is to point to a contrast between an actual situation and an expectation, agentivity and volitionality are no longer necessary.

Finally, a purely pragmatic stage is reached when by pointing to the action or process expressed by the verb, the speaker emphasises the assertion of it: something 'indeed' happens or has happened. This may or may not be unexpected or sudden, and the meaning components described above are often absent. 
(44) Latvian: 'indeed'

[Cik reižu nav dzirdēts prasām, lai "tie tur augš̄" vismaz reizēm "padomā par tautu” un ievēlējam taču tos, kuri "domā par tautu” visvairāk.]

$\begin{array}{llllll}\mathrm{Nu} & \text { viņi } & \text { tagad } & \text { ņem } & \text { un } & \text { domā, } \\ \text { PTC } & \text { 3.NOM.PL.M } & \text { now } & \text { take.PRS.3 } & \text { and } & \text { think.PRS.3 }\end{array}$

[a tādam darbam nekādu uzskaiti neiztaisīsi.]

"[How often have we not heard someone require that "those on top" (the ruling class) at least sometimes "think about the people". After all we elect those who more than others "think about the people".] Well, now they are indeed thinking, [but that's a job that defies bookkeeping.]'

The meanings discussed so far, which we argue derive from a "pointing to" the action or process denoted by V, are those found most often in text passages of narrative or descriptive genres. In various kinds of directives, on the other hand, emphasis of the action denoted by the lexical verb is directed to the hearer. Here, we do not find involuntary actions nor processes that "just happen", but instead actions that are supposed to be carried out consciously. The meaning of the construction is an enforcement of the directive: 'do it by all means', 'go ahead'. Various examples with imperatives given in this section illustrate this, for example, (8) ņem un nesmē 'go ahead and do something for once, don't whimper'. In addition to the imperative, this function is also found with various other verb forms that are used in directives, such as the Latvian construction with the particle lai, the debitive, or some infinitive constructions.

Some differences between Latvian and Lithuanian can be found when comparing collocation candidates of the construction (using the respective function in Sketch Engine). In both languages, words translating as 'suddenly' and as 'simply, just' are on the very top of the lists, but in a different order: in Lithuanian, staiga 'suddenly' is the most important collocate, while in Latvian, it is vienkāršsi 'simply, just'. This finding corresponds to our intuitions (based on intensive work with the corpus examples) that in Lithuanian the meaning of sudden, unexpected (beginning) of an action is more prominent, while in Latvian the meaning is vaguer and more often than in Lithuanian cannot be explained as unexpectedness. 


\section{The construction in Estonian and Finnish}

In Estonian, there are two variants of the TAKE (and) V construction. The first one, with the verb võtma 'take' alone, is relatively infrequent. Within a sample of 1000 random uses of VõTMA $j a \mathrm{~V}$ from the corpus etTenTen 13 , there were only 89 occurrences of the investigated construction. The other variant contains the phrasal verb kätte võtma, literally 'take into (one's) hand'. This variant is much more frequent. With the query [lemma="võtma"] [word="kätte"][][tag="V."] altogether 764 occurrences of the sequence were found; among the first 500 instances, 480 clauses represented the construction $(96 \%)$.

The construction võTMA $j a \mathrm{~V}$ mainly has an intentional meaning (Tragel 2017), as illustrated in (45). It means that the action expressed by $\mathrm{V}$ is or will be done intentionally, quite often putting some extra effort into it. This is true for both variants and evident especially with kätte võtma (46). The construction also has an ingressive meaning, i.e. it focuses on the starting point of the event, which seems to be a kind of decision-making or planning point.

(45) Estonian: hendiadic construction with võtma

Mina võtsin ja lugesin oma kirja

1SG.NOM take.PST.1SG and read.PST.1SG RPOSs letter.geN

läbi!

through

'I set my mind to it and read the letter'

(46) Estonian: hendiadic construction with kätte võtma

Siis võtsin kätte ja lindistasin

then take.PST.1SG hand.ILL and record.PST.1SG

mõned demod.

some.NOM.PL demo. NOM. PL

'I set my mind to it and recorded some demos'

One reason why kätte võtma is more usual in the construction can be related to grammatical aspect. In Estonian, grammatical aspect is expressed with particles belonging to verbs and with object case marking. Kätte 'into someone's hands' acts as a particle belonging to the verb 'take'. Semantically it is a logical endpoint of the event of TAKING and thus makes the event bounded, expressing thus that the decision is made at this point ('I made 
up my mind and ...). This interpretation is present also in non-literal usages, including this construction.

The construction is typically (but not always) accompanied with total object, which marks that the event has reached or may reach its inner endpoint and the object is quantitatively totally affected (cf. Metslang 2017). Total object can be marked either with genitive as in (45) or nominative as in (46). The construction (either with võtma or kätte võtma) tends to take total object and is accompanied with a particle expressing perfective aspect, e.g. läbi 'through' in (45).

In Finnish, we found the construction with the verb ottaa 'take' well represented in the corpus fiTenTen14_tt2, though it is less frequent than the construction in the Baltic languages. There were 531 instances of the construction in a random sample of 1000 instances of the sequence OTTAA $j a \mathrm{~V}$. Like in Estonian, the Finnish construction often denotes an agentive, intentional action as in (47).

(47) Finnish

\begin{tabular}{|c|c|c|c|c|}
\hline $\begin{array}{l}\text { Välillä } \\
\text { sometimes } \\
\text { vauhdilla } \\
\text { speed.ADE }\end{array}$ & $\begin{array}{l}\text { otan } \\
\text { take.PRs.1SG } \\
\text { loppuun, ... } \\
\text { end.ILL }\end{array}$ & $\begin{array}{l}j a \\
\text { and }\end{array}$ & $\begin{array}{l}\text { teen } \\
\text { do.PRS.1SG }\end{array}$ & $\begin{array}{l}\text { kaikki } \\
\text { all }\end{array}$ \\
\hline
\end{tabular}

There seems to be no Finnish equivalent to the Estonian variant with kätte võtma, which not only by frequency, but also with respect to its characteristics discussed in this section turned out to be the best Estonian instantiation of the TAKE (and) V construction.

\section{Person, tense and mood}

Although our sample of Estonian võtma ja $\mathrm{V}$ contains only 89 observations, it shows that the construction can be used with a wide range of person, tense and mood combinations (see Table 8), and the same is true for kätte võtma ja $\mathrm{V}$ (Table 9). The main difference between võtma and kätte võtma seems to be how often they are used in the past tense and imperative: kätte võtma shows higher occurrence in indicative past tense forms (as in (46)) while võtma is used more often in imperatives (48). In this respect, the Estonian construction with kätte võtma is closer to its Finnish counterpart than the construction with võtma (see Table 10 for Finnish), and it is also closer to the same construction in the Baltic languages in this respect. 
Table 8. Distribution of person, tense and mood forms in Estonian pseudocoordination with võtma

\begin{tabular}{|c|c|c|c|c|c|}
\hline & PRS & PST & IMP & COND & sum \\
\hline $1 \mathrm{SG}$ & 3 & 6 & & & 9 \\
\hline $2 S G$ & 8 & & 21 & & 29 \\
\hline $3 S G$ & 4 & 7 & 2 & 3 & 16 \\
\hline $1 \mathrm{PL}$ & 2 & 1 & & & 3 \\
\hline $2 \mathrm{PL}$ & & & 8 & & 8 \\
\hline $3 \mathrm{PL}$ & 2 & & & & 2 \\
\hline sum & 19 & 14 & 31 & 3 & 67 \\
\hline in $\%$ & $21.3 \%$ & $15.7 \%$ & $34.8 \%$ & $3.4 \%$ & $75 \cdot 3 \%$ \\
\hline impersonal & 1 & 3 & & & 4 \\
\hline infinitive 1 & 14 & & & & 14 \\
\hline infinitive 2 & 2 & & & & 2 \\
\hline participles & & 2 & & & 2 \\
\hline sum total & & & & & 89 \\
\hline
\end{tabular}

Table 9. Distribution of person, tense and mood forms in Estonian pseudocoordination with kätte võtma

\begin{tabular}{l|l|l|l|l|l}
\hline & PRS & PST & IMP & COND & Sum \\
\hline 1SG & 23 & 83 & & 3 & $\mathbf{1 0 9}$ \\
2SG & 18 & 0 & 42 & 1 & $\mathbf{6 1}$ \\
3SG & 52 & 74 & 7 & 29 & $\mathbf{1 6 2}$ \\
1PL & 11 & 15 & & 1 & 27 \\
2PL & 0 & 0 & 26 & & $\mathbf{2 6}$ \\
3PL & 18 & 30 & & 5 & 53 \\
Sum & 122 & 202 & 75 & 39 & 438 \\
in \% & $25.4 \%$ & $42.1 \%$ & $15.6 \%$ & $8.1 \%$ & $\mathbf{9 1 . 3}$ \\
impersonal & 5 & 5 & & & $\mathbf{1 0}$ \\
infinitive 1 & 20 & 0 & & & $\mathbf{2 0}$ \\
infinitive 2 & 1 & 0 & & & $\mathbf{1}$ \\
participles & 0 & 11 & & & $\mathbf{1 1}$ \\
sum total & & & & & 480
\end{tabular}


(48) Estonian

[Pagan, meie riik on selline, nagu me ta teinud oleme.]

Kui sulle ei meeldi,

if 2SG.ALL NEG please.CNG

võta ja HAKKA PAREMAKS TEGEMA /../

take.IMP.2SG and start.IMP.2SG better.TRL make.INF2

'[Damn, our country is the way we have made it.]

If you don't like it, set yourself to making it better.'

Also in Finnish, the construction can be used with a wide range of person, tense and mood combinations, as can be seen in Table 10. However, we can see that the 3 SG past tense forms dominate $(54 \%$,). Compared to Estonian, imperative is considerably less frequent.

Table 10. Distribution of person, tense and mood combinations in Finnish pseudocoordination with ottaa.

\begin{tabular}{l|l|l|l|l|l}
\hline & PRS & PST & IMP & COND & sum \\
\hline 1SG & 11 & 32 & & & 43 \\
2SG & 3 & & 11 & & 14 \\
3SG & 60 & 288 & & 11 & 359 \\
1PL & 1 & 2 & & & 3 \\
2PL & 0 & & 5 & & 5 \\
3PL sum & 84 & 334 & $\mathbf{1 6}$ & $\mathbf{1 1}$ & 445 \\
\multicolumn{1}{c|}{ in \% } & $\mathbf{1 5 . 8 \%}$ & $\mathbf{6 2 . 9 \%}$ & $\mathbf{3 . 0 \%}$ & $\mathbf{2 . 1 \%}$ & $\mathbf{8 3 . 8 \%}$ \\
impersonal & 5 & 4 & & & 9 \\
infinitive & 71 & & & & \\
3infinitive & 4 & & & & \\
perfect & 2 & & &
\end{tabular}

Compared to Estonian, Finnish ottaa ja $\mathrm{V}$ seems to have less intentionality in its meaning and the construction is often used for expressing events that happen without (expressed) external planning or intention (like in (49)). Such examples are rare in Estonian and may occur only with kätte 
võtma; in Baltic languages, however, unexpected non-intentional events are usual. Such usages as in (49) also explain why 3 rd person singular past tense forms are so frequent in Finnish (compared to Estonian).

(49) Finnish

$\begin{array}{lllll}\text { Sosialististen } & \text { Neuvostotasavaltojen } & \text { Liitto otti } & \text { ot } \\ \text { socialist.PL.GEN } & \text { Soviet_republic PL.GEN } & \text { union } & \text { take.PST.3SG } & \text { and } \\ \text { hajosi } & \text { lähes } & \text { parikymmentä } & \text { vuotta } & \text { sitten. } \\ \text { fall_apart.PST.3SG about twenty } & \text { year.PRT } & \text { ago } & \end{array}$

'The UssR unexpectedly fell apart almost twenty years ago.'

\section{Negation}

Estonian võtma (ja) V does not occur with negation, at least a series of corpus queries did not reveal any examples of it. It seems to be impossible to negate it without losing the constructional meaning, i.e. without losing the interpretation as one event. When example (50a) is negated as shown in (5ob), it sounds strange and can be interpreted only as two coordinated events, i.e. võtma gets literal interpretation.

(50) Estonian

a. Mina võtsin ja lugesin oma kirja

1SG.NOM take.PST.1SG and read.Pst.1SG RPOSS letter.GeN

läbi!

through

'I set my mind to it and read the letter.'

b. ?Ma ei võtnud ega/ja ei

1SG.NOM NEG take.PST.PA neither/and NEG

lugenud oma kirja läbi.

read.PST.PA RPOSS letter.PRT through

intended meaning: 'I didn't set my mind to it and (didn't) read the letter'

The only way to use the construction under negation seems to be as an infinitive of negated modal verbs. This works both with kätte võtma (51) and võtma.

(51) Estonian

$\begin{array}{llllll}\text { Uks } & \text { minister } \quad \text { ei } & \text { saa } & \text { kätte } & \text { võtta } \\ \text { one } & \text { minister.NOM NEG } & \text { can.CNG } & \text { hand.ILL } & \text { take.INF } \\ j a & \text { hakata mingit } & \text { asja } & \text { kellegi } & \\ \text { and } & \text { start.INF some.PRT } & \text { thing.PRT } & \text { someone.GEN } \\ \text { eest } & \text { menetlema. } & & & \\ \text { behalf } & \text { process.INF2 } & & & \end{array}$


'One minister cannot pick up and process some business on behalf of someone else.'

The construction kätte võtma ja $\mathrm{V}$ can be negated without changes in interpretation (52), although negation is still rare. Formally both predicates are negated.

(52) Estonian

Kuni ma tõepoolest ei võta kätte ja

until I.NOM indeed NEG take.cNG hand.ILL and

ei hakka seda lähtekoodi muutma.

NEG start.CNG this source_code.PRT change.INF2

'As long as I really do not pick up and change this source code myself' In both instances it is the whole construction that is negated: (can) NEG [TAKE and V].

In Finnish, the construction can be used in negation similarly to Estonian kätte võtma, but it is rare in Finnish as well: there are only a few instances of negation in our data. In Finnish, negation is formed with a negation verb inflected for person. In example (53), the negation verb is attached to the question word miksi 'why'. However, the example seems exceptional because semantically it is affirmative, although grammatically negative.

(53) Finnish

[paljon nähtävää,]

miksen siis vain ota ja lähde

why_NEG.1SG then just take.CNG and go.CNG

'[There are many things to see,]

why wouldn't I just take a chance to leave'

To conclude, both Estonian and Finnish do not use negation in the construction often. In Estonian, it is possible only with kätte võtma. Differently from Baltic languages, Finnic languages do not have the pattern TAKE and [NEG V], e.g. Estonian *võta-n ja ei tee (take-1SG and not do.CNG, '(I) take and don't do'). For forming the construction, both verbs have to have the same polarity.

\section{Cohesion}

According to Pulkkinen (1966) and Tragel (2003, 2017), in Estonian and other Finnic languages the construction can be used either with the coordinator $j a$ or without it (asyndetic construction). Sporadically in written Estonian also the coordinator ning 'and' is found. It has the same meaning 
as $j a$ 'and', but is remarkably less frequent in written texts (according to Kaalep and Muischnek 2002, 6, ning is 6.2 times less frequent than ja) and hardly occurs in spoken Estonian. In our data, ning was not used with the verb võtma, but occurred with kätte võtma.

Example (54) illustrates the asyndetic construction with võtma in Estonian. In written data, the two verbs are sometimes separated by a comma.

(54) Estonian

$\begin{array}{lllll}\text { Aga sina } & \text { võta } & \text { oota } & \text { ära, } & \text { millal } \\ \text { But you } & \text { take.IMP.2SG } & \text { wait.IMP.2SG } & \text { away } & \text { when } \\ \text { testi } & \text { teha } & \text { ja }[\ldots] & & \\ \text { test.PRT } & \text { make.INF } & \text { and } & & \end{array}$

'But wait until you can do the test.'

In Table 11, the use of some of the most frequent person forms with and without a coordinator is compared. We see that in written data the use of the coordinator is more common, but the asyndetic construction is not rare. Interestingly, it is not the imperative that shows the strongest tendency to drop the coordinator. These data were obtained by additional queries.

Table 11. Occurrence of the coordinator in some frequent forms of Estonian võtma ja $\mathrm{V}$

\begin{tabular}{l|l|l|l}
\hline Person form & $j \boldsymbol{j}$ 'and' & No coordinator & \% of using $\boldsymbol{j a}$ \\
\hline IMP.2SG & 103 & 52 & $66 \%$ \\
IMP.2PL & 48 & 16 & $75 \%$ \\
PRS.1SG & 11 & 9 & $55 \%$ \\
PRS.3SG & 12 & 27 & $31 \%$
\end{tabular}

In Finnish, the asyndetic variant is attested as well, but it is rare in comparison to the construction with the coordinator. A comma is rarely used in this construction. A query on past tense personal forms revealed that there were 66 instances of the asyndetic variant without comma in the whole corpus (as in 55), and only 7 instances with a comma.

(55) Finnish

$\begin{array}{llll}\text { Hän } & \text { otti } & \text { vaihtoi } & \text { kortteja. } \\ \text { s/he } & \text { take.PST.3SG } & \text { change.PST.3SG } & \text { card.PL.PRT }\end{array}$

'He/she changed the cards.' 
Estonian kätte võtma $(j a) \mathrm{V}$ is more strongly used with the coordinator than võtma $(\mathrm{ja}) \mathrm{V}$. Of the 480 instances in our sample, 431 have the coordinator ja, 23 the coordinator ning (see examples (57) and (62)), and 26 show combinations without coordinator but with a comma; there are no examples of asyndetic combination without a comma. Thus, in this construction, ja (or ning) seems to be more tightly attached to the construction than with võtma (ja) V. Interestingly, some usages imply that using comma indicates that the parts of the construction are not so closely related as with $j a$ : there are often more than two verbs in the clause and it can more easily be interpreted as common coordination. The following example is similar to the observations in Baltic where the last verb indicates a kind of final result.

(56) Estonian

$\begin{array}{lllll}\text { Võta } & \text { kätte, } & \text { oppi } & \text { arstiks } & j a \\ \text { take.IMP.2SG } & \text { hand.ILL } & \text { learn.IMP.2SG } & \text { doctor.TRL } & \text { and } \\ \text { päästa } & k o g u & \text { maailm! } & & \\ \text { save.IMP.2SG } & \text { whole } & \text { world.NOM } & & \\ \text { 'Just study medicine and save the world!' } & \end{array}$

Thus in both Estonian and Finnish the construction without a coordinator is well attested, but the use of the coordinator is more frequent - with the Estonian construction with kätte võtma and in Finnish, the asyndetic variant is rare.

In Estonian and Finnish TAKE and V constructions, the tense and person of TAKE and the following verb must be the same, otherwise they do not form the hendiadic construction.

However, Estonian kätte võtma ja V sometimes exhibits a mismatch in the uses of grammatical tenses. While verbs in võtma (ja) V are always used in the same grammatical form, kätte võtma ja $\mathrm{V}$ has more flexibility in it. Examples like (57) indicate that there is also an option to interpret the clause as expressing two related events, or at least the event can be interpreted as having two parts: the first part (kätte võtma) expresses decision-making or the starting point, and the second part expresses the main event. However, interestingly, in this clause the subject is inanimate and thus is not able to make decisions, neither can things live (as expressed in the second part).

(57) Estonian

[Sina tegid omale mugava nurga,]

$\begin{array}{llllll}\text { aga } & \text { ASJAD } & \text { võtsid } & \text { kätte } & \text { ning } & \text { elavad } \\ \text { but } & \text { thing.PL } & \text { take.PST.3PL } & \text { hand.ILL } & \text { and } & \text { live.PRS.3PL }\end{array}$


hoopis sinust sõltumatut elu.

quite 2SG.ELA independent.PRT life.PRT

'[You made a comfortable corner for yourself]

but THINGs live their own lives'

\section{Lexical variation of $\mathrm{V}_{2}$}

Estonian võtma ja $\mathrm{V}$ can take as a second verb only agentive verbs like tegema 'do, make', lugema 'read', sööma 'eat', hakkama 'start', viima 'bring', minema 'go', vaatama 'look at', kasutama 'use', sõitma 'drive' etc. It means that volitionality and intentionality are related to the use of the construction, and the construction takes only animate subjects. Both transitive and intransitive verbs can be used. Clauses with ja and without it do not show any difference in this respect.

(58) Estonian

$\begin{array}{lcccc}\text { Sa } & \text { ära } & \text { kõgise, } & m a & \text { võtan, } \\ \text { 2SG.NOM } & \text { NEG } & \text { grumble.IMP.2SG } & \text { 1SG.NOM } & \text { take.1SG } \\ \text { vaatan } & \text { järgi } & & \\ \text { look.PRS.1SG } & \text { after } & & \end{array}$

'Don't grumble, I'll go check'

(59) Estonian

[Lubasin endale praegu,]

et võtan ja tuletan mõned

that take.PRS.1SG and recall.PRs.1SG some.NOM.PL

nõiduslikud kohad jälle meelde.

mysterious.NOM.PL place.NOM.PL again mind.ILL

'[Now I promised myself] that I'd try and remember some mysterious places.'

Interestingly, kätte võtma ja $\mathrm{V}$ shows more variability in the choice of V. Here too the most frequent verbs (among 480 examples of the construction) are agentive transitive or intransitive verbs: tegema 'do, make' (75 occurrences), hakkama 'start' (49), minema 'go' (38), kirjutama 'write' (24), lugema 'read' (14), panema 'put' (14), sõitma 'drive' (10). However, we can also find examples such as surema 'die' or põdema 'suffer' that express clearly non-agentive, unintentional events.

(6o) Estonian

[.. ning siis oleks nagu koolnukangestus kallale tulnud,] sekundipealt võttis kätte ja suri ära. second_by take.PST.3Sg hand.ILL and die.PST.3sg away '[And then there was like rigor mortis,] all at once [he/she] died.' 
(61) Estonian

$\begin{array}{llll}\text { Meie } \quad \text { võtsime } & \text { kätte } & \text { ja } & \text { põdesime } \\ \text { 1PL.NOM take.PST.1PL } & \text { hand.ILL } & \text { and } & \text { suffer.PST.1PL } \\ \text { tuulerõuged } & \text { läbi... } & & \\ \text { chicken_pox.NOM.PL } & \text { through } & & \\ \text { 'We suffered through chicken pox' } & \end{array}$

Also inanimate subjects can be used with kätte võtma, but typically they are shown as being volitional agents, see (62).

(62) Estonian

[ Ja siis läheb mööda mõni ensü̈̈m või koputab keegi ärritav valk tüviraku uksele,]

$\begin{array}{lllll}\text { see võtab } & \text { kätte } & \text { ning } & \text { hakkab } & \text { arenema ... } \\ \text { it take.PRS.3SG hand.ILL } & \text { and } & \text { start.PRS.3SG } & \text { develop.INF } \\ \text { näiteks } & \text { ajurakuks. } & & & \\ \text { for_example } & \text { brain_cell.TRL } & & & \end{array}$

'[And then an enzyme passes by or an irritating protein knocks on the stem cell's door,] it decides to develop ... for example into a brain cell.'

In Finnish, the choice of verbs in the construction is less restricted than in Estonian (esp. in comparison to Estonian võtma ja V) and in this respect, Finnish is closer to the Baltic languages than Estonian. Both transitive and intransitive verbs can be used in the construction. Just as in Estonian, agentive, volitional verbs are frequent, such as vaihtaa 'replace, change', käyttää 'use', lukea 'read', ostaa 'buy', palkata 'employ', panna 'put', vähentää 'decrease', valloittaa 'conquer', kirjoittaa 'write', liittää 'join, connect', lähteä 'leave', juosta 'run', käydä 'visit, go to', liittyä 'join', mennä 'go' etc. See, e.g., ex. (47) and (55).

However, in Finnish we also found a considerable number of examples with non-agentive verbs, especially verbs denoting a change of state, ${ }^{10}$ such as sairastua 'get sick', sammua 'flame out', kaatua 'fall', kuolla 'die', hajota 'fall apart', nukahtaa 'fall asleep', etc., as in (63-65). As can be seen in the examples, the construction can be used also with inanimate subjects, similarly to Baltic languages.

\footnotetext{
${ }^{10}$ That these verbs are common in the Finnish construction can also be inferred from the fact that two out of three examples in the comprehensive Finnish grammar (Hakulinen et al. 2004, 1041) contain a verb indicating a change of state (syttyä 'catch fire, ignite', kaatua 'fall'; the third one is 'leave'), and one of the examples contains an inanimate subject.
} 
(63) Finnish

fa sitten se mies otti ja kuoli.

and then this.NOM man.NOM take.PST.3Sg and die.PST.3SG

'And then this man just died.'

(64) Finnish

$\begin{array}{lllll}\text { Ritun auto } & \text { ottaa } & \text { ja hajoaa } & \text { kesken } \\ \text { Ritu.GEN car.NOM } & \text { take.PRS.3SG } & \text { and fall_apart.PRS.3SG } & \text { middle } \\ \text { kaiken: } & \text { polttoainetta } & \text { valuu } & \text { tielle... } & \\ \text { everything.GEN } & \text { petrol.PRT } & \text { run.PRS.3SG street.ALL } & \end{array}$

'Ritu's car breaks in the middle of everything: petrol runs on the street'

(65) Finnish

$\begin{array}{ll}\text { Rahat } & \text { kun ottivat ja loppuivat } \\ \text { money.NOM.PL } & \text { then take.PST.3PL and end.PST.3SG } \\ \text { heti } & \text { alkuunsa. } \\ \text { right } & \text { beginning.ILL.POss3 } \\ \text { 'The money surprisingly ran out at the very beginning.' }\end{array}$

By the choice of lexical verbs in the second position, it can be seen that Finnish is somewhat closer to the use of the same construction in Baltic languages than to Estonian. The construction can be used both for expressing intentional actions and for unintentional, non-volitional events with inanimates. In the last examples we can see that the construction may express also unexpected negative events with inanimate subjects. In Estonian, this can be done only with kätte võtma ja $\mathrm{V}$, but is still rare. Estonian võtma ja $\mathrm{V}$ does not allow such usages at all and is limited to intentional events where TAKE expresses rather a planning point of the action.

In Estonian it mostly emphasises that the action is carried out intentionally and decidedly; the same can be found in Finnish. Estonian kätte võtma ja $\mathrm{V}$ and Finnish ottaa ja $\mathrm{V}$ often indicate unexpectedness. The Finnish grammar (Hakulinen et al. 2004, 1041), describes the meaning of the construction shortly as "unexpected event" ("odottamaton tapahtuma"). This indicates that unexpectedness is at least one central meaning of the construction, though it is not the only one attested in our sample. Estonian dictionaries include some examples of the constructions, explaining the meaning of TAKE in the construction as "assuring the action expressed with the second verb" (for võtma $+\mathrm{V}$ ) or 'get on with it, take something to do it' (for kätte võtma $+\mathrm{V}$ ) (EKSs). 


\section{The construction in Polish and Russian}

The take (and) V construction exists in both Polish and Russian (Slavic in general; cf. Ross 2017). In both languages, the verb 'take' can appear in perfective (Pol. wziać and Rus. vzjat) or imperfective (Pol. brać and Rus. brat) form. The perfective is significantly more common (see figures in Table 1 in Section 2). If not otherwise indicated, examples in this Section are taken from the corpora plTenTen 12 and ruTenTen 11.

\section{Person, tense and mood}

In both languages, the construction is well attested with various verb forms. More than $40 \%$ of all usages of the perfective form are in the past, as in example (70). In Russian, a similarly significant number of examples of the construction are in the infinitive form (example 66). Cf. Tables 12-13.

(66) Polish

[Na catym świecie modlito się, ]

aby nie umierat,

so_that NEG die(IPFV).PST.3SG.M

a on wziat $i$

but 3SG.M.NOM take(PFv).PST.3SG.M and

umart

die(PFV).PST.3SG.M

'In the whole world people prayed that he wouldn't die, but he died [regardless].

(67) Russian

$\begin{array}{llc}\begin{array}{l}\text { Stranno, čto } \\ \text { weird.N that }\end{array} & \begin{array}{l}\text { Izrail' možno prosto tak } \\ \text { vzjat' }\end{array} \quad i \quad \begin{array}{l}\text { Israel possible just_like_that } \\ \text { take(PFv).INF }\end{array} \text { and fly(PFv).INF } \\ \text { 'It is weird that one can fly to Israel just like that.' }\end{array}$

Specific of Russian is the use of the construction in the so-called narrative imperative, which describes an unexpected event in the past. Morphologically, the narrative imperative is always IMP.2SG and does not agree with the subject, see (68).

(68) Russian

A medsestra voz'mi $i$ otlučis'.

and nurse.NOM.SG take(PFV).IMP.2SG and leave(PFV).IMP.2SG

'And the nurse [unexpectedly] went away' 
Out of 29 examples of IMP.2SG that we classified as our construction, 14 have the narrative reading. The narrative imperative is possible only with the perfective form of the verb 'take'.

Tables 12-13 show the distribution of all possible forms with perfective and imperfective verbs across both languages in the construction. To compare the use of the construction with other uses of TAKE, the numbers for overall usage of the latter are also provided.

Table 12. Distribution of inflectional forms in Polish

\begin{tabular}{|c|c|c|c|c|c|c|c|c|}
\hline & $\begin{array}{c}\text { TAKE } \\
\& \mathrm{~V}\end{array}$ & $\%$ & all $\mathrm{T}$ & $\%$ & $\mathrm{~T} \& \mathrm{~V}$ & $\%$ & all T & $\%$ \\
\hline \multicolumn{5}{|c|}{ wziąć } & \multicolumn{4}{|c|}{ brać } \\
\hline PST & 306 & $46 \%$ & 704444 & $40 \%$ & 17 & $6 \%$ & 486027 & $27 \%$ \\
\hline NON-PST & 119 & $18 \%$ & 306927 & $18 \%$ & 89 & $33 \%$ & 893836 & $49 \%$ \\
\hline ANAL.FUT & & & & & 3 & $1 \%$ & 21294 & $1 \%$ \\
\hline IMP & 127 & $19 \%$ & 223072 & $13 \%$ & 58 & $22 \%$ & 76381 & $4 \%$ \\
\hline IRR & 1 & $0.1 \%$ & 16701 & $1 \%$ & 2 & $1 \%$ & 9024 & $0.5 \%$ \\
\hline INF & 117 & $17 \%$ & 492445 & $28 \%$ & 98 & $37 \%$ & 344498 & $19 \%$ \\
\hline Total & 670 & $100 \%$ & 1743589 & $100 \%$ & 267 & $100 \%$ & 1831060 & $100 \%$ \\
\hline
\end{tabular}

Table 13. Distribution of inflectional forms in Russian

\begin{tabular}{|c|c|c|c|c|c|c|c|c|}
\hline & $\begin{array}{c}\text { TAKE } \\
\& \mathrm{~V}\end{array}$ & $\%$ & all T & $\%$ & $\begin{array}{c}\text { TAKE } \\
\& \mathrm{~V}\end{array}$ & $\%$ & all $\mathrm{T}$ & $\%$ \\
\hline \multicolumn{5}{|c|}{ vzjat' } & \multicolumn{4}{|c|}{ brat' } \\
\hline PST + IRR & 348 & $43 \%$ & 1535856 & $39 \%$ & 19 & $4 \%$ & 391811 & $16 \%$ \\
\hline NON-PST & 85 & $10 \%$ & 500358 & $13 \%$ & 236 & $52 \%$ & 1139754 & $46 \%$ \\
\hline IMP & 56 & $7 \%$ & 389006 & $10 \%$ & 125 & $28 \%$ & 171467 & $7 \%$ \\
\hline INF & 324 & $40 \%$ & 1506417 & $38 \%$ & 74 & $16 \%$ & 761826 & $31 \%$ \\
\hline Total & 813 & $100 \%$ & 3931637 & $100 \%$ & 454 & $100 \%$ & 2464858 & $100 \%$ \\
\hline
\end{tabular}

The non-past verb forms are more common with the imperfective form, i.e. they have present tense meanings ( $52 \%$ of all examples in Russian, and $33 \%$ in Polish). The imperfective form is somewhat rare in the past tense 
( $4 \%$ in Russian, and $8 \%$ in Polish). Such misbalance between perfective and imperfective forms in the past and present might hint "that our construction has not yet reached the final stage of aspectual pairedness" (this claim was made for Russian by Weiss 2007, 432). It is worth noting that while in Baltic the imperative is rare in this construction, in both Slavic languages, and especially in Polish, utterances with the imperatives are quite frequent, rounding around $20 \%$ of all examples (it is least frequent with Russian vzjat', only $6.8 \%$ ).

In both languages the perfective verb for TAKE may combine with an imperfective second verb, even though this phenomenon occurs in different contexts: in Polish in imperative and past, and in Russian in past and simple future (cf. Andrason 2018, 592-593 for Polish; Fortuin 2000, 152 and Weiss 2007, 429-430 for Russian). In Russian, the aspectual difference between the verbs in the construction in the past is usually accompanied by a difference in tense: the 'take' verb is in the past, and the lexical verb is in the historical present. In our sample, there was one example where TAKE was used in the narrative imperative and the second verb in present tense, (69); however not all speakers accept such examples as grammatical.

(69) Russian

[Vylovil kak-to mužik prekrasnuju rusalku.]

$\begin{array}{lllll}A & t a & \text { voz'mi } & i & \text { govorit } \\ \text { and } & \text { DEM.NOM.SG.F } & \text { take(PFV).IMP.2SG and } & \text { say(IPFV).PRS.3SG } \\ \text { jemu } & \text { barxatnym } & \text { goloskom... } & \\ \text { 3SG.M.DAT } & \text { velvet.INS.SG.M } & \text { voice.DIM.INS.SG } & \end{array}$

'[Once a man caught a beautiful mermaid.] And she [suddenly] tells him in a mellow voice...'

\section{Negation}

Both patterns of negation found in Baltic are also attested in Russian and Polish. The negative marker is a free morpheme, otherwise the patterns are also formally the same as in Baltic: with only one negative marker placed directly before $\mathrm{V}$, the abstract meanings of TAKE are retained (70), while the whole construction is negated by formally negating both TAKE and $\mathrm{V}$ individually (71).

(70) Polish, Pattern 1: TAKe and [NEg V]

[Przyjechali w nadziei, że spotkaja się oko w oko z „premierem z Krakowa”,]

$\begin{array}{lllll}a & \text { ten } & \text { wziąt } & i & \text { nie } \\ \text { but } & \text { DEM.NOM.SG.M } & \text { take(PFV).PST.SG.M } & \text { and } & \text { NEG }\end{array}$


przyjechat na "marsz niepodlegtości”.

come(PFV).PST.SG.M to march.NOM.SG independence.GEN.SG

'[They came in the hope to meet the "prime minister from Kraków" face to face,] but he did not come to the "march of independence".'

(71) Polish, Pattern 2: NEg [TAKE and V]

[Bo pies sobie nie pójdzie,]

nie weźmie $i$ nie kupi

NEG take(PFV)NPST.3SG and NEG buy(PFv).NPST.3SG

jedzenia.

food.GEN.SG

'[For a dog will not go (to the shop)], it will not buy food (itself).'

In the literature on Russian, only the first pattern has been reported so far (Weiss 2007, 4; Stojnova 2007, 187). However, the second pattern is also attested in our sample:

(72) Russian

$\begin{array}{lllrll}\text { Počemu by } & \text { mne vot tak } & \text { ne } & \text { vzjat' } \\ \text { why } & \text { IRR } & \text { 1SG.DAT like_this NEG } & \text { take(PFV)INF } \\ i & n e & & \text { otpravitsja } & v & k \text { osmos? } \\ \text { and NEG } & \text { PVB.set_off(PFV)INF.RFL } & \text { in } & \text { space }\end{array}$

'Why shouldn't I just set off to space?'

This pattern is contextually limited and usually appears in contexts of potential situations (as in (72), in a question). There is no wonder it is several times less frequent than the first pattern.

In Russian, both negation patterns are possible with perfective and imperfective forms of TAKE. Example (73) shows the imperfective verb.

(73) Russian

Nikogda serdce ot etogo

never heart.NOM.SG from DEM.GEN.SG.N

ne beret $i$ ne ostanavlivajetsja.

NEG take(IPFV).NPST.3SG and NEG stop(IPFV).NPST.3SG.RFL

'Never does a heart [unexpectedly] stop because of it.'

In Polish, negation seems to occur only with the perfective verb. Both patterns are equally frequent (66 observations of Pattern 1 and 67 of Pattern 2). As in other languages, neither pattern of negation is particularly frequent, and negation of the TAKE and V construction may be a source of confusion or give rise to explicit comment. This is shown in the following example, where the speaker does not oppose two logical options but two forms of negation, presumably having the same content in mind. 
(74) Polish

$\begin{array}{llllll}\text { Edwardzie! } & \text { Ty } & \text { byś } & \text { pewnie } & w & \text { tej } \\ \text { Edward.vOC } & \text { 2SG.NOM } & \text { IRR.2SG } & \text { surely } & \text { in } & \text { DEM.LOC.SG.F } \\ \text { sytuacji } & \text { wziąt } & i & \text { nie } & \text { umart. } \\ \text { situation.LOC.SG } & \text { take(PFV).PST.3.M } & \text { and } & \text { NEG } & \text { die(PFV).PST.3.M } \\ \begin{array}{llll}\text { Albo tez } \\ \text { or also }\end{array} & \text { wEg } & \text { take(PFV).PST.3.M } & \text { and } & \text { NEG } & \text { die(PFV).PST.3.M }\end{array}$

'Edward! You surely would have not-died in this situation.

Or [should I say] would not have died?? :)'

There are some further interesting observations regarding the negation of imperatives in Polish, where a couple of interpretations are possible. The first is a straightforward directive: the negated lexical verb expresses an activity that should not be done or continued.

(75) Polish: negation of imperatives with TAKE and NEG-V type a.

$\begin{array}{lll}\text { Weź } & i \quad \text { nie } & \text { gadaj- } \\ \text { take(PFV).IMP.2.SG } & \text { and NEG } & \text { talk(IPFV).IMP.2.SG } \\ \text { powiedziat } & \text { stanowczo, } & \text { więc } \\ \text { say(PFV).PST.3SG.M } & \text { resolutely } & \text { so } \\ \text { ustapiłem. } & \\ \begin{array}{l}\text { concede(PFV).PST.M.1SG } \\ \text { '“Stop talking," he said resolutely, so I stopped.' }\end{array}\end{array}$

The second one is more puzzling, because negation is used somewhat ironically. The outcome of the action expressed by the negated lexical verb is about to happen, i.e. given price is a bargain and it is wise to use it:

(76) Polish: negation of imperatives with TAKE and NEG-V type b [67 złotych bodajże na fan.pl.]

No weźz $i$ nie weź.

PTC take(PFv).IMP.2.SG and NEG take(PFV).IMP.2.sG

' 67 zlotys on fan.pl, it is a must take.' ('how could I go ahead and not take it')

Another interesting observation is a difference between the variant with the coordinator and the asyndetic variant. It seems that the latter cannot be used with the second pattern of negation, while it is quite usual with the first (in the last two examples, the coordinator $i$ could be omitted without change of meaning). The following example shows a (joking) answer to a command: while the positive imperative uses the asyndetic form, its negation in the response is formulated using the coordinator. 
(77) Polish (context: the speaker was annoyed about continuous questioning about Christmas presents)

\begin{tabular}{llll}
-A & weź & \multicolumn{2}{c}{ przestań!! } \\
PTC & take(PFV).IMP.2.SG & \multicolumn{2}{c}{ stop(PFV).IMP.2SG } \\
- Nie & wezme & $i$ & nie \\
NEG & take(PFV).NPST.1SG & and & NEG \\
przestane & jutro & & Wigilia! \\
stop(PFV).NPST.1SG & tomorrow & Christmas_Eve.NOM.SG \\
'[A:] Stop it! [B:] I won't stop, it's Christmas Eve tomorrow.'
\end{tabular}

Finally, we also found 8 examples in the Polish corpus where only the first verb was negated. However, all of these observations look like errors of some sort and sound odd. Despite the fact that the meaning of the sentences is rather clear, it feels like the negation of the second verb is missing. Formally only wziąc is negated, but the scope of negation is over the whole construction, it therefore represents the second pattern: NEG [TAKE and V].

(78) Polish (not standard, not accepted by all speakers)

[A skąd mamy wiedzieć że]

$\begin{array}{llcll}\text { go } & \text { nie } & \text { weźmiesz } & & i \\ \text { 3SG.M.ACC } & \text { NEG } & \text { take(PFV).NPST.2.SG } & \text { and } \\ \text { umieścisz } & & \text { gdzieśs } & w & \text { sieci. } \\ \text { upload(PFV).NPST.2SG } & \text { somewhere } & \text { in } & \text { net.LOC.SG }\end{array}$

'How should we know that you will not upload it | somewhere on the Internet?'

While this construction is not part of contemporary standard Polish, it might be a further development where the TAKE (and) V construction is considered as a complex form of a verb and consequently needs only one marker of negation with scope over the whole.

\section{Cohesion}

The TAKE (and) V construction in both languages shows a high degree of cohesion. The construction most commonly consists of exactly these three elements, however there might be a number of interrupting words, such as adverbs or in Polish the reflexive marker się. Similar to Baltic, arguments and adverbs are usually placed before or after the construction, but some variation occurs. The observations discussed in this section were obtained by additional queries. 


\section{Presence vs absence of 'and'}

In contrast to Russian and to Baltic, in Polish the asyndetic type TAKE V is quite frequent, although it is less frequent than TAKE and V with the coordinator. It is especially common in colloquial registers with an imperative (79).

(79) Polish

$\begin{array}{llll}\text { Lepiej } & \text { weź } & \text { sprawdź } & \text { sobie } \\ \text { better } & \text { take(PFV).IMP.2SG } & \text { check(PFV). IMP.2SG } & \text { RFL.DAT } \\ \text { jak } & \text { powstawała } & \text { ksiażka. } & \\ \text { how } & \text { arise(PFV).PST.3SG.F } & \text { book.NOM.SG } & \\ \text { 'Better check how the book was created.' } & \end{array}$

As noted by Andrason $(2018,585)$, the use of the coordinator may even be ungrammatical in frequent combinations such as Weź $\left({ }^{*} i\right)$ przestań!'Stop it!' (see (82) above). Interestingly, the insertion of the coordinator may lead to a different interpretation: Weź i przestań! 'How could I stop?' (with irony). The properties of the asyndetic TAKE V construction in Polish lead Andrason (2018) to categorise it as a serial verb construction.

In Russian the asyndetic construction is rare. The following is one of a few examples we found in the corpus.

(8o) Russian

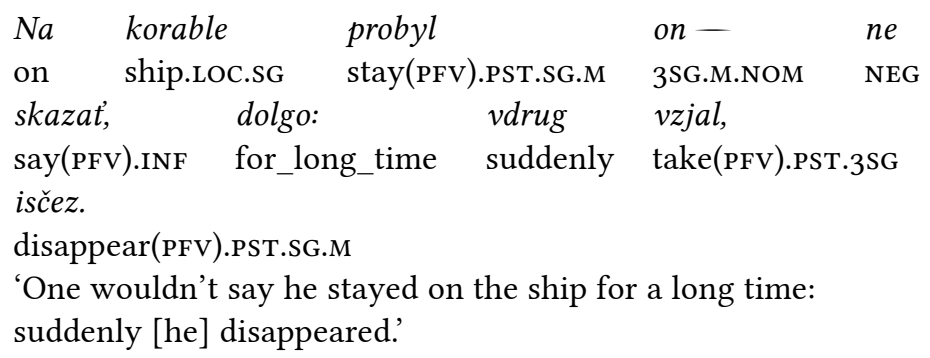

Weiss (2007) lists the following formal types of the Russian TAKE (and) V construction:

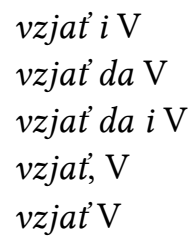

The very last subtype is considered "the starting point of verbal serialisation" (Weiss 2007, 428). It differs prosodically (one stress on the lexical 
verb) and morphosyntactically from other subtypes, for instance, it allows fronting of the lexical verb, as in (81). The other subtypes require strict verb order, first 'take' and then a lexical verb.

(81) Russian (Fortuin 2000, 154-155)

$\begin{array}{lcl}\text { kakoj } & \text { vy } & \text { otec?. } \\ \text { what_kind.NOM.SG.M } & \text { 2PL.NOM } & \text { father.NOM.SG } \\ \text { Udavljus' } & \text { vot voz'mu! } \\ \text { strangle_oneself(PFv).NPST.1SG } & \text { PTC take(PFv).NPST.1SG } \\ \text { 'What kind of father are you? ... I will strangle myself!” }\end{array}$

This subtype is specific of Russian and does not have correlates in the other languages under discussion. Weiss (2007) also mentions cases when the lexical verb is not present or an interjection is used instead of it, as in (82):

(82) Russian (Weiss 2007, 3)

$\begin{array}{llll}\text { On } & v z j a l & i & b u x ! \\ \text { 3SG.NOM.M } & \text { take(PFv).PST.3SG } & \text { and } & \text { splash! } \\ v & \text { vodu. } & & \\ \text { in } & \text { water.ACC.SG } & & \end{array}$

'All of a sudden, he fell / dived into the water.'

\section{Placement of arguments, adverbs and particles}

In both languages, some elements may be placed into the construction, and usually they are single elements. In Polish it is not rare to see a direct object placed after wziać or before the lexical verb, especially pronouns, but more complex phrases are also possible, as in (83). Also adverbs such as tylko 'only', nagle 'suddenly', po prostu 'simply' may be inserted either after TAKE or between 'and' and V.

(83) Polish

\begin{tabular}{|c|c|c|c|}
\hline No & to & wzięta & sanie \\
\hline PTC & PTC & take.PST.3SG.F & sleigh.ACc.PL \\
\hline razem & $z e$ & stodota & podpalita. \\
\hline gether & with & barn.INS.SG & set_fire.PST.3SG.F \\
\hline
\end{tabular}

While in Russian and in Baltic the reflexive marker is a bound morph, in Polish it is a free word (sie), and it is found in different positions inside and outside of the hendiadic construction. In clauses with the TAKE (and) $\mathrm{V}$ construction, it is not always clear whether a się belongs to the lexical verb, to 'take', or to both. More detailed research is needed. In the following 
examples some of the variation can be seen. In (84) and (87) się is placed in front of the construction, although it seems to belong to the lexical verb (rozchorować sie 'fall ill', rozpadać się 'start to rain'). Thus, it is treated as belonging to the complex.

\section{Lexical variation of $\mathrm{V} 2$}

In both languages, the construction can be used with animate as well as inanimate subjects (concrete and abstract entities) and also with zero-valent verbs. As in Baltic, the construction is used not only for actions carried out intentionally by an actor, but also for involuntary changes of state. So far in this section we showed mostly examples with intentional human actors, so we will add here some illustrations of other types of subjects and verbs. We did not notice any significant difference between Polish and Russian with respect to lexical classes of verbs and subjects.

(84) Polish (human undergoer, involuntary change of state)

[Planowany tydzień skracaliśmy do 4 dni,]

bo sie ten maluch wziąt

because RFL this infant.NOM.SG take(PFV).PST.3SG.M

i rozchorowat.

and fall_sick(PFv).PST.3SG.M

'[We shortened the planned week to 4 days,]

because our little one fell sick.'

(85) Russian (inanimate concrete subject, undergoer)

[V takoj termos možno nalit’ čaj, $i$ vse kak budto $v$ porjadke,]

a potom on voz'met

and then 3SG.NOM.M take(PFV).PRS.3SG

i vzorvetsja.

and explode(PFV).PRS.3SG.RFL

'[You can pour tea in such a thermos, and everything will be seemingly ok,] but then it will [suddenly] explode.'

(86) Russian (inanimate abstract subject, change of state)

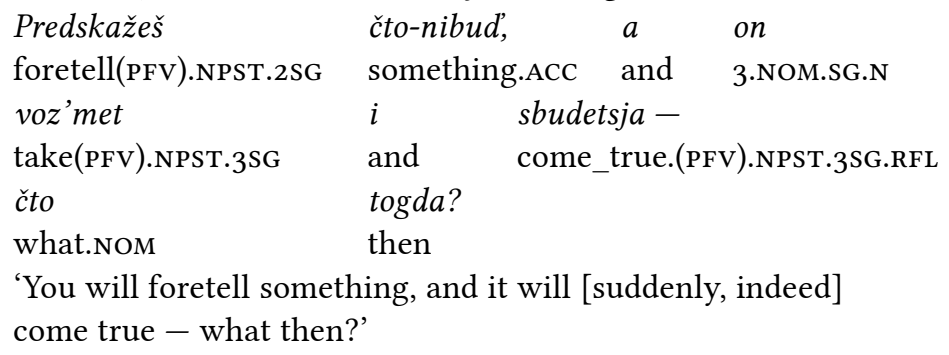


(87) Polish (weather verb)

[Rano, gdy już wlazłem we wszystkie te ciuchy,]

się wzięto $i$ rozpadato

RFL take(PFV).PST.3SG.N and PVB.rain(PFV).PST.3SG.N

'[In the morning, when I got into all these clothes,] it started to rain.'

In both Russian and Polish the construction usually cannot be used with unbounded activities and states like 'sleep', 'be asleep', 'believe', 'rain'. Examples with such predicates found in Latvian and Lithuanian could (according to several consultants) not be translated into Polish or Russian with the TAKE (and) V construction.

\section{Semantics}

The semantics of the construction is similar in both languages. Similar to the Baltic languages, the meaning most often may be paraphrased by 'suddenly', 'unexpectedly', 'contrary to the usual situation or norm', 'contrary to my will', 'all by itself', 'without apparent reason', 'indeed', and others.

Judging by the Russian data, the meaning 'all by itself, without reason' seems to be dominant with the imperfective verb for 'take', whereas the pure meaning of unexpectedness is more frequent with the perfective form.

A special case is the imperative (not narrative) use of the construction. It differs semantically from other grammatical forms, because the imperative cancels the unexpectedness. Fortuin $(2000,152)$ formulates that in Russian "...the vzjat'-construction is used to eliminate the addressee's possible hesitation to do the action". Thus, as described for Baltic, with an imperative the meaning of the construction is something like 'go ahead', 'just do it', and not 'do it suddenly / against expectations'. The same is true for Polish.

\section{Discussion and conclusions}

In the preceding Sections $3-5$ we assembled data from six languages from three genetic groups, of which two, Baltic and Slavic, are branches of one family. The three groups have been in an areal relationship since prehistoric times, and contacts between two or more individual languages have played a role at various times in history. However, the similarities we find in the form and function of the TAKE and $\mathrm{V}$ construction do not seem to closely follow genetic relationship (except for Baltic) or contact histories. Moreover, two constructions in one language may be more different than 
constructions across languages. We may assume that the constructions have been developing for a considerable time mostly language-internally, and that similarities across languages are connected to general factors rather than to shared heritage or mutual influences. However, the similarities between Latvian and Lithuanian are striking. Though constructions in all six languages have much in common, the Baltic languages still stand out with respect to frequency and functional range of the construction. We therefore conclude that there is a Baltic type of the TAKE (and) V construction, whose features are found to a varying degree in neighbouring languages.

In this section we will compare the six languages according to four basic research questions, compiling and discussing the findings of the previous sections:

- How frequent and conventional (grammaticalised) is the construction?

- Which inflectional forms are most prominent for the construction?

- Which kind of verbs and subjects are used in the construction?

- What are the meanings and functions of the construction?

\subsection{How much of a construction is TAKE and V?}

In Section 2 we explained how we extracted the investigated construction from the corpora. A first indicator of the degree of conventionalisation of the construction was the percentage of "good" examples in a sample of occurrences of the sequence of the lemma 'take', followed by 'and' and a verb. The exact figures were given in Table 1. Accordingly, we may arrange the languages on a scale as given in Table 14 .

Table 14. How great a portion of instances of a sequence TAKE and $V$ represent the construction?

\begin{tabular}{l|l|l}
\hline Percentage & \multicolumn{1}{|c}{$\begin{array}{c}\text { Language, } \\
\text { construction }\end{array}$} & \multicolumn{1}{|c}{$\begin{array}{c}\text { Degree of } \\
\text { conventionalisation }\end{array}$} \\
\hline$>90 \%$ & Lithuanian; Estonian verb + particle & high \\
$>80 \%$ & Latvian; Russian perfective & \\
$>60 \%$ & Polish perfective & medium \\
$>50 \%$ & Finnish & \\
$>40 \%$ & Russian imperfective & \\
$>25 \%$ & Polish imperfective & low \\
$<10 \%$ & Estonian simple verb &
\end{tabular}


A construction that is a conventional pairing of form and meaning does not have to be frequent. However, three of the four top constructions in Table 14 are also the most frequent in our corpora. In Table 15 we present the frequency with which the constructions are represented in the corpora. For Lithuanian and Latvian all occurrences are considered, while the figures for the other languages are based on an estimate, assuming that the percentage of good examples in the whole corpus corresponds to the percentage of good examples in the random sample that we filtered manually. ${ }^{11}$

Table 15. Frequency of hendiadic TAKE and V in the corpora (per million)

\begin{tabular}{ll|l}
\hline Lithuanian imti ir $\mathrm{V}$ & & 19.37 \\
Latvian ņemt un $\mathrm{V}$ & 5.83 \\
Russian vzjat' $i \mathrm{~V}$ & (perfective verb) & 4.76 \\
Finnish ottaa ja $\mathrm{V}$ & & 3.37 \\
Estonian võtma kätte [] V & (particle verb) & 2.81 \\
Estonian võtma ja $\mathrm{V}$ & (simple verb) & 1.56 \\
Polish wziać $i \mathrm{~V}$ & (perfective verb) & 0.73 \\
Russian brat' $i \mathrm{~V}$ & (imperfective verb) & 0.66 \\
Polish brać $i \mathrm{~V}$ & (imperfective verb) & 0.28
\end{tabular}

The hierarchy implied in Table 15 corresponds to our intuition and expert knowledge of the languages, though the large difference between Lithuanian and Latvian came as a surprise. Thus, the construction is well established in the Baltic languages and in Russian, to a lesser degree in Finnish and Estonian. In standard Polish the construction is rather rare.

${ }^{11}$ For example, for Finnish $53.1 \%$ of a random sample of 1000 represented the construction, so we assumed that $53.1 \%$ of the total of 8923 observations of the sequence $(=4738)$ would represent the construction in the corpus of 1,404,100,049 words, which gave us the figure of $3 \cdot 37$ per million. 
In the languages using both a perfective and an imperfective expression for 'take' (Russian, Polish, Estonian), pseudocoordination is more frequent with the perfective verb.

One reason for the lower frequency of the TAKE and V construction in Polish in our comparison is that in that language we find more syntagmatic variability. While in the Baltic languages, the most important form of the construction is the one we searched for in our initial query, in Polish the asyndetic variant TAKE (,) $\mathrm{V}$ is quite frequent. We also more often find elements such as pronouns inserted into the construction, and such variants are not included in our counts. Though not as frequent as the construction with the coordinator, asyndetic TAKE $\mathrm{V}$ is salient in colloquial registers of Polish, which may be the reason that it has received more attention among linguists than the variant with the coordinator. In Estonian, the construction with the simple verb is also quite frequent without coordinator, while the construction with the particle verb behaves more like Baltic in this respect. Finnish in turn has a very strong preference for using the coordinator; asyndetic forms were judged as odd by native speaker consultants. The asyndetic construction and its relation to the coordinated construction is certainly worth further investigation in Polish and also in Estonian, but for the Baltic languages and Finnish it seems to be of less interest, at least in the modern standard varieties. ${ }^{12}$

\subsection{Grammatical categories: Tense, mood, aspect, polarity}

In Table 16 we have compiled the frequencies of the most important forms in which 'take' and the lexical verb are used in the hendiadic construction (only the variant with 'and' was counted). Note that the comparison glosses over language-specific differences. The Slavic and Finnic languages have a non-past category rather than present and future tense. In Latvian, we did not distinguish imperative from present tense (see Section 3).

${ }^{12}$ In the comprehensive grammar of Finnish (Hakulinen et al. 2004, 1041), the construction is partly described in the section on coordination, and an asyndetic variant is not mentioned at all. 
Table 16. Distribution of most important verb forms

\begin{tabular}{l|c|c|c|c|c|c|l}
\hline \multicolumn{1}{c|}{ Language } & PRS & IMP & PST & FUT & IRR & INF & 100\% \\
\hline Latvian & \multicolumn{2}{|c|}{40.2} & 21.0 & 11.5 & 2.4 & 20.0 & 3093 \\
Lithuanian & 24.5 & 8.4 & 28.7 & 15.6 & 5.3 & 15.6 & 943 \\
Estonian kätte võtma & 25.4 & 15.6 & 42.1 & - & 8.1 & 4.4 & 480 \\
Estonian võtma & 21.3 & 34.8 & 15.7 & - & 3.4 & 18.0 & 89 \\
Finnish & 15.8 & 3.0 & 62.9 & - & 2.1 & 13.4 & 531 \\
Polish wziać́ & - & 19.0 & 45.7 & 17.7 & 0.1 & 17.5 & 670 \\
Russian vzjat' & - & 6.9 & 41.4 & 10.4 & 1.2 & 40.0 & 817 \\
Polish brać & 33.3 & 21.7 & 8.2 & - & - & 36.7 & 267 \\
Russian brat' & 52.0 & 27.5 & 4.2 & - & - & 16.3 & 454
\end{tabular}

Some languages use the construction most often in past tense, most clearly Finnish with over 60\%, but also Estonian with kätte võtma, and Polish and Russian ${ }^{13}$ with perfective 'take'. Also in Lithuanian, past tense forms are more frequent than others, but the distribution is more balanced. In Latvian, past tense is less frequent compared to Lithuanian, but we found that it is significantly more frequent in our construction than in other uses of the verb n,emt 'take'. The Slavic constructions with imperfective 'take' clearly prefer present tense over past tense. With these verbs, also imperatives are more important. Interestingly, in Polish also in constructions with perfective 'take' the imperative has a significant share of almost $20 \%$. In fact, imperatives are the first forms that come to people's minds when asked about examples for the construction wziać $i \mathrm{~V}$. It is possible that the imperative (especially the 2sG weź $i \mathrm{~V}$ ), despite being less frequent in corpora than third person past tense, has got its prominence through certain exemplars typical for slang. The highest share of imperatives was found with Estonian võtma. A low share of imperatives (less than 10\%) was found in the Baltic languages, in Russian (perfective) and especially in

\footnotetext{
${ }^{13}$ Stojnova (2007, 160-161) states a much higher preference than we found for the past tense with the Russian perfective vzjat', "about $70 \%$ " of her sample.
} 
Finnish. However, in Lithuanian imperative is used in pseudocoordination significantly more often than elsewhere.

It is interesting that the highest frequency of imperative forms occurs in the constructions that are least frequent (cf. Table 15) and less conventionalised (cohesive) (cf. Table 14).

\section{Aspect}

In Polish and Russian, where aspect is an established grammatical category, there is a marked difference between the use of perfective and imperfective 'take'. The construction is more frequent, more versatile, and more similar to Baltic with the perfective form. In Estonian, there is a similar and still more pronounced difference between the simple verb and the particle verb. While the Estonian simple verb is neutral with respect to aspect (rather than being imperfective), the particle verb is a conventional means of expressing perfective aspect in Estonian (together with object marking). Thus, not only in Slavic, but also in Estonian we see a preference of the construction for perfective aspect. Finnish, on the other hand, has no perfectivising particles, and the verb ottaa 'take' is aspectually neutral.

Where do the Baltic languages fit in here? On the one hand, one may argue that the simple verbs for 'take' (Ltv. nemt, Lith. imti) are aspectually neutral, just as their equivalent in Finnish. On the other hand, they do stand in a partly grammaticalised opposition to verbs with a semantically neutral prefix: Ltv. pa-ņemt, Lith. pa-imti. On this background we may state that in contrast to Slavic (and Estonian), Baltic uses an imperfective verb for TAKE, or maybe rather: does not prefer a perfective verb. This may be an argument for the thesis that the Baltic construction has developed independently from the Slavic construction, or if not independently, then certainly not after a Slavic model. In fact, in Latvian the use of panemt in pseudocoordination is often attributed to Russian influence, the proper Latvian form being simple n,emt. The use of the prefixed verb in Latvian needs further investigation. In Lithuanian, we have shown that it is by far less frequent than the simple verb (77 observations $=1.5^{8}$ per million).

\section{Negation}

Negation is found in two patterns that differ formally and with respect to scope. In the first pattern, negation has scope only over the lexical verb $\mathrm{V}$, while the meaning components conveyed by TAKE are not negated: TAKE 
[NEG V]. In the Baltic languages, negation is expressed by a prefix attached to the verb $\mathrm{V}$, while in the Slavic languages it is a free particle positioned immediately before $\mathrm{V}$, for example Latvian ņēma un neieradās '(unexpectedly) did not show up' (cf. 7), Polish wziąt i nie przyjechat '(unexpectedly) did not come' (70). In the Finnic languages, this pattern is not found: the verb 'take' and the lexical verb V must have the same polarity.

In the second pattern, negation has scope over the whole construction: NEG [TAKE and V]. In Baltic and Slavic this pattern is realised through formally negating both verbs, for example Polish nie weźmie i nie kupi jedzenia 'will not buy food' (71). This pattern is usually found in non-real contexts or contexts describing potential situations. This pattern is significantly less frequent than the first one.

In Estonian, this pattern is (marginally) found with the phrasal verb kätte võtma, but not with võtma alone. Also in Finnish, it appears but rarely.

Table 17. Negation patterns found with the investigated constructions

\begin{tabular}{l|c|c|c|c|c|c|c|c|c}
\hline \multicolumn{1}{c|}{ Language } & LTV & LIT & $\begin{array}{c}\text { EST } \\
\boldsymbol{v} .\end{array}$ & $\begin{array}{c}\text { EST } \\
k . \boldsymbol{V} .\end{array}$ & FIN & $\begin{array}{c}\text { POL } \\
\text { PFV }\end{array}$ & $\begin{array}{c}\text { RUS } \\
\text { PFV }\end{array}$ & $\begin{array}{c}\text { POL } \\
\text { IPFV }\end{array}$ & $\begin{array}{c}\text { RUS } \\
\text { IPFV }\end{array}$ \\
\hline $\begin{array}{l}\text { Pattern 1: } \\
\text { TAKE and [NEG V] }\end{array}$ & $\checkmark$ & $\checkmark$ & - & - & - & $\checkmark$ & $\checkmark$ & - & $\checkmark$ \\
$\begin{array}{l}\text { Pattern 2: } \\
\text { NEG [TAKE and V] }\end{array}$ & $\checkmark$ & $\checkmark$ & - & $\checkmark$ & $\checkmark$ & $\checkmark$ & $\checkmark$ & - & $\checkmark$
\end{tabular}

In Polish both patterns of negation are equally frequent, but they are possible only with perfective 'take'. In the other languages which have both patterns, the second is clearly less frequent than the first. Even if it is possible to put TAKE under the scope of negation, this is rarely done. A third logically possible pattern, where only TAKE would be negated, "[NEG TAKE] and V", is not attested in any of the languages. This is to be expected, as the meanings of TAKE become more grammatical - grammatical categories are not negated by the common means of negation.

At present, languages that have the second pattern formally use two instances of the negating element. A further step into grammaticalising the construction would be to drop the second negator. Constructed example in Polish: ?nie [weźmie i kupi jedzenia], intended meaning as in nie weźmie $i$ nie kupi jedzenia 'will not buy food'. We found a few such examples in Polish, but they are not accepted by all native speakers, or they are ambiguous between the hendiadic construction and a literal interpretation of 'take'. 


\subsection{Lexical-semantic variation in subjects and lexical verbs}

The lexical meaning of the verb 'take' involves an animate (most commonly human) agent and a voluntary action. In some languages which have a similar TAKE and $\mathrm{V}$ construction, this construction is restricted to agentive verbs and/or to actions carried out intentionally. In these languages, if a non-intentional verb is used in this construction (such as 'disappear'), it is implied that the action is carried out "as if" intentionally. This is the situation described for Norwegian by Vannebo (2003, 172-173). Similarly, for varieties of American English that have a "TAKE and V" construction, Krivochen \& Schmerling $\left(2016,5^{-6}\right)$ show that it is only used for deliberate actions (while this restriction is not observed for pseudocoordination with go and with up). Ekberg (1993) postulates that not only in Swedish, but cross-linguistically, the TAKE and $\mathrm{V}$ construction encodes volitionality so that "a verb which is neutral (or ambiguous) with respect to volitionality gets an unambiguously volitional reading" (Ekberg 1993, 33) and the verbs such as 'be murdered', 'cry', 'fall', "which take a nonvolitional subject role are incompatible with take and" (Ekberg 1993, 34) ${ }^{14}$ This is not true for our languages.

Our languages of investigation have taken the TAKE and V construction farther, although the majority of observations still involve activities that can be controlled by the actor and consequently are used most often with human subjects. These features are inherited from the literal meaning of 'take' (here we agree with Ekberg 1993), and they characterise the prototype of the construction, at least in its initial stages. The Estonian construction with the simple verb võtma seems to have stayed closest to this prototype: it is used only with agentive verbs and requires volitional, human subjects. With the particle verb kätte võtma, the Estonian construction can also take patientive, non-volitional verbs such as 'die', but it is still largely restricted to human subjects. In examples with other subjects, these are treated as if they were volitional (such as in 57 things living their own life, or in 62 an enzyme knocking on a door). The other languages do not

\footnotetext{
${ }^{14}$ Note that some of the "impossible" constructed examples given by Ekberg (1993) for Finnish and Polish are indeed attested in our samples. See also Fortuin $(2000,158)$ for the fact that Ekberg's claims do not hold for Russian.
} 
show this restriction. Especially in the Baltic languages and Finnish, we noticed a prominent set of verbs denoting a change of state of inanimate undergoers: cars breaking down, states falling apart, things disappearing, dreams (or fears) coming true. Such examples are also attested in Polish and Russian. These verbs are at the centre of a new prototype of the construction. It is probably here that the meaning 'unexpectedly' comes to the fore. Finally, only in the Baltic languages we found the TAKE and V construction with unbounded activities and states, such as 'rain', 'sleep', 'believe'. This is (still) rare, and some Lithuanian examples we discussed with native speakers got different interpretations - for example, 'it takes and is raining' in one and the same example was interpreted by some as 'it started to rain suddenly and continues to rain' and by others as 'it is raining against my expectations/against my wishes'. Some translated examples seemed to be marginally acceptable in Russian, but only in past tense, not present tense.

Taking into account only intransitive verbs, we may roughly distinguish three types of verbs and arrange them on a scale as shown in Table 18.

Table 18. Occurrence of lexical-semantic types of intransitive verbs in the TAKE and $V$ construction

\begin{tabular}{|c|c|c|c|c|}
\hline Type & Verbs & Subjects & Example & Language \\
\hline 1 & $\begin{array}{l}\text { intentional } \\
\text { actions }\end{array}$ & $\begin{array}{l}\text { human } \\
\text { actor }\end{array}$ & 'leave' & $\begin{array}{l}\text { Norwegian, English } \\
\text { LTV, LIT, RUS, POL, FIN, EST } \\
\text { (both verbs) }\end{array}$ \\
\hline $2 a$ & $\begin{array}{l}\text { change } \\
\text { of state }\end{array}$ & $\begin{array}{l}\text { human } \\
\text { undergoer }\end{array}$ & $\begin{array}{l}\text { 'die' } \\
\text { 'fall ill' }\end{array}$ & $\begin{array}{l}\text { LTV, LIT, RUS, POL, FIN, EST } \\
\text { (particle verb) }\end{array}$ \\
\hline $2 b$ & $\begin{array}{l}\text { change } \\
\text { of state }\end{array}$ & $\begin{array}{l}\text { inanimate } \\
\text { concrete / } \\
\text { abstract }\end{array}$ & $\begin{array}{l}\text { 'fall to pieces' } \\
\text { 'turn sour' } \\
\text { 'start raining' } \\
\text { 'come true' }\end{array}$ & $\begin{array}{l}\text { LTV, LIT, RUS, } \\
\text { POL, FIN }\end{array}$ \\
\hline 3 & $\begin{array}{l}\text { state, } \\
\text { unbounded } \\
\text { activity }\end{array}$ & all & $\begin{array}{l}\text { 'sleep (be asleep)' } \\
\text { 'rain (be raining)' } \\
\text { 'believe' }\end{array}$ & $\begin{array}{l}\text { LTV, LIT } \\
\text { (states are still } \\
\text { exceptional) }\end{array}$ \\
\hline
\end{tabular}


While we did not conduct a diachronic study and historical sources for the construction are hard to come by in our languages, we find it likely that the "types" in Table 18 also represent stages in the spread of pseudocoordination with TAKE through the lexicon of a language.

\subsection{The meaning(s) of the construction}

There have been several attempts to ascribe the hendiadic construction TAKE (and) V a single meaning, both within one language and for a larger group of languages. Coseriu (1966) reviewed and criticised several earlier attempts, for example, the view that the construction essentially has ingressive meaning. He then proposed his own, very general interpretation of the construction in all European languages where it is attested: according to Coseriu, the construction expresses the holisticity of the action expressed by the second verb ("drückt die Wendung die Gesamtheitlichkeit der von dem zweiten Verb bezeichneten Handlung aus", Coseriu 1966, 42). ${ }^{15}$ While we find this concept of "holisticity" rather vague and do not see how to apply it to our data, we are more sympathetic with Coseriu's further thesis that the various concrete meanings the construction may have arise as context-dependent interpretations of a general function. In Section 3.4 we showed that most of the functions of the construction in Latvian can be related to the general function of explicitly pointing to the action or process expressed by the second verb. The alternative to such an approach would be to ascribe several concrete meanings to the construction, thus treating it as polysemous. In any case it seems clear that the construction does not have just one special meaning, but its interpretation depends on several factors. Although the meanings of suddenness and unexpectedness are very often present, in our view calling the construction an "inexpectative" ${ }^{16}$ fails to pay full justice to its range of meanings and functions. Cf. also Fortuin (2000, 156-161) for a differentiated account of the meaning of the Russian construction.

We have found and shown in several places in this paper that the meaning of an individual instance of the construction depends on the function

${ }^{15}$ Fortuin $(2000,157)$ translates Coseriu's Gesamtheitlichkeit as "unity and indivisibility", but we tried to imitate the strangeness Coseriu's term has to a German reader by coining the term holisticity.

${ }^{16}$ Weiss $(2008,334)$ speaks of the Russian construction as "die "Inexpektativ"-Konstruktion" 
of the utterance (and related to that, the inflectional form of the verb) and on lexical-semantic properties of the second verb. As a first step it seems to be necessary to distinguish between directives (mostly containing an imperative form) and narrative or descriptive uses. Within the latter, the meaning of the verb plays a greater role. With agentive verbs the meaning of intentional, decided actions is emphasised by the construction; unexpectedness may be part of the meaning, but this is not always the case (especially not with first person subjects). With patientive verbs expressing an uncontrolled change of state, on the other hand, it is mostly unexpectedness that is signaled by the construction. Additionally we often find a negative stance towards this unexpected event (or sometimes irony and other attitudinal nuances). With all verbs there may also be a secondary function of affirming the statement that $\mathrm{V}$ happens. This function may become primary with ongoing situations expressed by durative or even stative verbs. Often, the meaning of the construction can be described as 'indeed'. Thus, when we move down the scale given in Table 18, the function of the construction becomes more pragmatic, speaker-related and discourse-related.

\subsection{Conclusions}

This research started out from a wish to investigate, document and describe the TAKE (and) V construction in the Baltic languages, where its existence has been known to linguists for at least a hundred years without ever getting a thorough description. Working in a larger team opened the possibility of including studies on Finnic and Slavic languages with the same method and comparable data. The result not only enabled us to get a broader picture of the construction, viewing it in areally related languages, but also helped us better understand and appreciate the construction in contemporary Latvian and Lithuanian. As it turned out, it is the Baltic languages where the construction is the most frequent, the most fixed in a certain form, and the most versatile in combining with the widest range of verbs and serving a range of mutually related functions.

The following features characterise the Baltic type of the TAKE (and) V construction:

- a strong preference for the use of the coordinator over the asyndetic variant; 
- a wide distribution of verb forms in which the construction occurs, with a relatively minor role of the imperative;

- two patterns of negation with the abstract meanings of TAKE outside or (more rarely) inside the scope of negation;

- a possible scope of TAKE over more than one following verb;

- a preference for agentive verbs and human actors, but also

- a well attested use with patientive verbs and inanimate undergoers;

- unexpectedness as one recurrent meaning;

- pragmatic meanings such as expressing stance and affirmation;

- the possibility to use the construction with unbounded activities and states.

The analysed constructions in the other languages share many of these features and differ in where they deviate from this type. Most similar is the Russian construction with perfective vzjat'. However, Russian has additionally developed several special features with the TAKE (and) V construction which are not found in any of the other languages. Polish stands out with a wider use of the asyndetic variant and of the imperative. Of the Finnic languages, it is sometimes Finnish and sometimes Estonian (with the particle verb) that is more similar to Baltic.

\section{AbBreviations}

1,2, 3 - first, second, third person, ACC - accusative, ADE - adessive, ADV - adverb, ALL - allative, ANAL.FUT - analytic future, CAUS - causative, CNG - connegative (verb form), COMP - comparative, CVB - converb, DAT - dative, DEF - definite, DEM - demonstrative, DIM - diminutive, ELA - elative, EMPH - emphatic pronoun, F - feminine, fut - future, GEN - genitive, HAB - habitual, ILL - illative, IMP - imperative, INE inessive, INF - infinitive, INF2 - second infinitive (supine), INS - instrumental, IPFV - imperfective, IRR - irrealis, LOC - locative, M - masculine, $\mathrm{N}$ - neuter, NEG - negation, NOM - nominative, NPST - non-past, $\mathrm{PA}$ - active participle, $\mathrm{PFV}$ - perfective, $\mathrm{PFX}$ - prefix, PL - plural, POss - possessive, PP - passive participle, PRS - present, PRT - partitive, PST - past, PTC - particle, PVB - preverb, RFL - reflexive, RPOSS - reflexive possessive pronoun, SG - singular, TRL - translative, v - verb, vOC - vocative 


\section{CORPORA}

(all corpora are available at the platform sketchengine.eu)

Latvian: lvTenTen14 (530,367,474 words)

Lithuanian: LithuanianWaC_v2, (48,650,918 words)

Estonian: etTenTen13 (260,559,829 words)

Finnish: fiTenTen14_tt2 (1,404,100,049 words)

Polish: plTenTen12 (7,715,835,214 words)

Russian: ruTenTen11 (14,553,856,113 words)

\section{REFERENCES}

Airola, Anu. 2007. Coordinated verb pairs in texts. PhD Dissertation.

Publications No. 41. University of Helsinki. Available at: http://hdl. handle.net/10138/19253, accessed June 5, 2019.

AmbrazAs, V[YTAUTAs]. 1965. Lietuvių kalbos dalyvių ir vieksmažodžių konstrukcijos su ir bei jų slaviški atitikmenys. [Lithuanian verb and participle constructions with ir 'and' and their Slavic equivalents]. Baltistica $1.1,53-66$.

Andrason, Alexander. 2018. The wziąć gram in Polish: A serial verb construction, or not? sTuF Sprachtypologie und Universalienforschung 71.4, 577-629.

Andrason, Alexander. 2019. A pseudo-coordinated serial verb construction "wziąć i V2" in Polish. Slovo a slovesnost 80.3, 163-191.

BARTMIŃSKI, JERZY. 1978. Swoiste formy orzeczeń w języku ustnym (orzeczenie onomatopeiczne, kompozycjonalne, zaimkowe, podwojone). [Peculiar predicate forms in spoken language (onomatopoeic, compositional, pronominal, and double predicates)]. In Studia nad składnia polszczyzny mówionej [Studies in Spoken Polish Syntax], Wrocław etc.: Ossolineum, 159-175.

BąBA, StanisŁaw \& StanisŁaw MikoŁajCzyk. 1974. O orzeczeniu szeregowym [The serial predicate]. Poradnik Jezykowy 4. 117-128.

Biberauer, Theresa \& Sten Vikner. 2015 (manuscript). Pseudo-coordination in Danish and Afrikaans. Published electronically, version 19.05.2015

Coseriu, E[Ugenio]. 1966. «Tomo y me voy». Ein Problem vergleichender europäischer Syntax. Vox Romanica 25, 13-55. 
Coseriu, Eugenio. 1977. «Tomo y me voy»: Un problema de sintaxis comparada europea. Estudios de lingüística románica. Madrid, Gredos, 79-151.

DLKž = Dabartinés lietuviu kalbos žodynas [Dictionary of Contemporary Lithuanian]. Updated electronic edition 2017. Ed. in chief Stasys Keinys. Available at: lkiis.lki.lt.

Ekberg, LenA. 1993. The cognitive basis of the meaning and function of crosslinguistic take and V. Belgian fournal of Linguistics 8. Perspectives on Language and Conceptualization, 21-41.

EKss $=$ Eesti keele seletav sõnaraamat [Explanatory Dictionary of Estonian], 2nd edition, ed. by Margit Langemets, Mai Tiits, Tiia Valdre, Leidi Veskis, Ülle Viks, Piret Voll. Tallinn: Eesti Keele Sihtasutus. 2009. Online: http://www.eki.ee/dict/ekss/ekss.html, last visited November 23, 2019.

Fortuin, Egbert L. J. 2000. Polysemy or Monosemy: Interpretation of the Imperative and the Dative-Infinitive Construction in Russian. $\mathrm{PhD}$ dissertation, University of Amsterdam.

Fraenkel, ERnst. 1921. Baltoslavica. Beiträge zur balto-slavischen Grammatik und Syntax. (Ergänzungsheft zur Zeitschrift für vergleichende Sprachforschung auf dem Gebiete der indogermanischen Sprachen, Nr. 1).

Göttingen: Vandenhoeck und Ruprecht.

Fraenkel, Ernst. 1926. Zur Parataxe und Hypotaxe im Griechischen, Baltoslawischen und Albanischen. Indogermanische Forschungen 24, 290-315.

GębKa-Wolak, Małgorzata. 2012. Weź się zastanów! Problem statusu gramatycznego przyimperatywnego weź [Weź się zastanów! The problem of the grammatical status of imperatival weź 'take']. Poradnik Jezzykowy 4. 49-63.

GórAlCZYK, IwONA. 2010. Weź, pokochaj smoka. The wziąć construction in Polish: A Construction Grammar analysis. Prace Językoznawcze 12. 89-104.

Hakulinen, Auli, Maria Vilkuna, Rittta Korhonen, Vesa Koivisto, Tarja Rittta Heinonen \& IrJa Alho. 2004. Iso suomen kielioppi. [Comprehensive Grammar of Finnish] sKs:n toimituksia (sKST) 950. Helsinki: Suomalaisen Kirjallisuuden Seura.

Haslinger, Irene \& van Koppen, Marjo. 2003. De verbale hendiadys als pseudocoördinatie [Verbal hendiadys as pseudocoordination].

Taal \& Tongval themanr. 15-16 (2002-2003), 102-122.

Hopper, PAul. 2002. Hendiadys and auxiliation in English. In: Joan Bybee \& Michael Noonan, eds., Complex Sentences in Grammar and Discourse: Essays in Honour of Sandra A. Thompson, Amsterdam-Philadelphia: John Benjamins, 145-174. 
Hopper, PAul. 2008. Emergent serialisation in English: Pragmatics and typology. In: Jeff Good, ed., Linguistic Universals and Language Change. Oxford: Oxford University Press, 253-284.

Ivulāne, BAIBA. 2015. Palīgnozìmē lietotu darbības vārdu sistēma latviešu valod $\bar{a}$ [The system of verbs with auxiliary meaning in Latvian]. $\mathrm{PhD}$ thesis, University of Latvia, Riga.

Jakubíček, Miloš, Adam Kilgarriff, Vojtěch Kovář, Pavel Rychlý \& Vít Suchomel. 2013. The TenTen Corpus Family. 7th International Corpus Linguistics Conference CL, 125-127. Available online at https://www. sketchengine.eu/wp-content/uploads/The_TenTen_Corpus_2013.pdf, accessed November 16, 2019.

KAALEP, HeIKI-JAAN \& KADRI MuIschneK. 2002. Eesti kirjakeele sagedussõnastik. [The frequency dictionary of Written Estonian]. Tartu: Tartu University Press.

Kilgarriff, Adam, Siva Reddy, Jan Pomikálek \& Avinesh PVS. 2010.

A corpus factory for many languages. Proceedings of LREC 2010. Available online at http://www.lrec-conf.org/proceedings/lrec2010/summaries/79. html, accessed November 16, 2019.

KInN, ToRodD. 2018. Pseudocoordination in Norwegian: Degrees of grammaticalization and constructional variants. In: Evie Coussé, Peter Andersson, and Joel Olofsson, eds., Constructional Approaches to Language 21, AmsterdamPhiladelphia: John Benjamins, 75-106. https://doi.org/10.1075/cal.21.c4.

Komorowska EwA. 2008. Pragmatyka dyrektywnych aktów mowy w języku polskim [The pragmatics of directive speech acts in Polish]. SzczecinRostock.

Kor Chahine, Irina. 2007. O vozmožnom puti grammatikalizacii russkogo "vzjat'" [On a possible grammaticalisation path of Russian vzjat' 'take']. Russian Linguistics 31.3, 231-248.

Krivochen, Diego Gabriel \& Susan F. Schmerling. 2016 (manuscript). Mirage Coordinations in English. Unpublished paper available at https:// www.academia.edu/25110015/_Squib_Mirage_Coordinations_in_English, accessed November 16, 2019.

Kvist DARnell, U. 2008. Pseudosamordningar i svenska: särskilt sådana med verben sitta, ligga och stå [Pseudocoordination in Swedish, especially with the verbs sitta 'sit', ligga 'lie' and stå 'stand']. Stockholm: Institutionen för lingvistik.

LEWy, ERnst. 1937. Erzjamordwinisches sajems «nehmen» perfektivierend. Finnisch-Ugrische Forschungen 24, 288-291.

LEWy, Ernst. 1951. Ein Nachtrag. Finnisch-Ugrische Forschungen 30, 284-288. 
LKŽ = Lietuviu kalbos žodynas [Dictionary of Lithuanian] (t. I-XX, 1941-2002): elektroninis variantas. Updated version 2017. Ed. in chief Gertrūda Naktinienè. Vilnius: Lietuvių kalbos institutas, Available at www.lkz.lt.

LLVV = Latviešu literārās valodas vārdnìca. [Dictionary of Standard Latvian]. Vol. 6.1 N̦-P. 1986. Editor in Chief R. Grabis. Rīga: Zinātne.

LøDRup, Helge. 2017. Norwegian Pseudocoordination with the Verb drive 'carry on': Control, raising, grammaticalization. In: Miriam Butt \& Tracy Holloway King, eds., Proceedings of the LFG'17 Conference, University of Konstanz. Stanford, CA: CSLI Publications, 264-284.

LVV= Latviešu valodas vārdnīca [Dictionary of Latvian]. 1987. Editor in chief Dainuvīte Guḷevska. Rīga: Avots.

Metslang, Helle. 2017. Sihitis [Object]. In: Mati Erelt \& Helle Metslang, eds., Eesti keele süntaks [Estonian syntax]. Eesti keele varamu III. Tartu: Tartu University Press, 258-277.

Poutsma, H. 1917. Hendiadys in English. Together with some observations on the constructions of certain verbs. Neophilologus 2, 202-218.

Pulkkinen, PaAvo. 1966. Asyndeettinen rinnastus suomen kielessä [Asyndetic coordination in Finnish]. Helsinki: Suomalaisen Kirjallisuuden Seura.

Ross, DANIEL. 2014. El origen de los estudios sobre la pseudocoordinación verbal. [The origin of research on verbal pseudocoordination]. Diálogo de la Lengua 6. Available at http://www.dialogodelalengua.com/articulo/numero6.html.

Ross, DANIEL. 2016. Between coordination and subordination: Typological, structural and diachronic perspectives on pseudocoordination. In Fernande Pratas, Sandra Pereira, Clara Pinto, eds., Coordination and Subordination: Form and Meaning. Selected Papers from CSI Lisbon 2014. Newcastle upon Tyne: Cambridge Scholars Publishing, 209-243.

Ross, DANIEL. 2017. Pseudocoordinación del tipo tomar y en Eurasia: 50 años después [Pseudocoordination with take and in Eurasia: 50 years later]. Presented at Lingüística Coseriana VI, Lima, Peru. Presentation available at http://publish.illinois.edu/djross3/files/2013/11/Ross-tomar-y.pdf.

Ross, Daniel. Forthcoming. Pseudocoordination, Serial Verb Constructions and Multi-Verb Predicates: The Relationship between Form and Structure. University of Illinois at Urbana-Champaign PhD dissertation.

ŠKodová, Svatava. 2009. Pseudokoordinace v syntaxi současné češtiny [Pseudocoordination in the syntax of contemporary Czech]. $\mathrm{PhD}$ dissertation, Prague. 
Stojnova, Natalia M. 2007. Konstrukcija $v z^{\prime} a t^{\prime} i$ sdelat'v russkom jazyke [The construction $v z$ 'at' $i$ sdelat' 'take and do' in Russian]. In: F. I. Dudčuk, N. V. Ivlieva \& A. V. Podobrjaev, eds., Struktury i interpretacii: raboty molodyx issledovatelej po teoretičeskoj i prikladnoj lingvistike. Moscow, 158-188.

Taube, Moshe. Draft. Verbal hendiadys in Yiddish. [downloaded 10.10.2009, was announced as "to appear" in Yiddish and Typology, eds. Neil Jacobs et $a l .$, this book has never appeared, but the draft is still online].

Tragel, ILONA. 2003. Seriaalkonstruktsioonist eesti keeles [On serial constructions in Estonian]. Keel ja Kirjandus, 12, 919-934.

TrAgEL, ILONA. 2017. Serial verb constructions in Estonian. In: Brian Nolan \& Elke Diedrichsen, eds., Argument Realisation in Complex Predicates and Complex Events: Verb-Verb Constructions at the Syntax-Semantics Interface. Amsterdam-Philadelphia: John Benjamins, 169-189.

VANNebo, KJELl IVAR. 2003. Ta og ro deg ned noen hakk: On pseudocoordinations with the verb 'take' in a grammaticalization perspective. Nordic Journal of Linguistics 26, 165-198

WeISS, DANIEL. 2007. The grammar of surprise: the Russian construction of the type Кошка взяла да умерла 'Suddenly, the cat died'. In: Tilman Reuther, Leo Wanner \& Kim Gerdes, eds., Proceedings of the 3rd International Conference on Meaning-Text Theory (Wiener Slawistischer Almanach, Sonderband 69). München, Wien: Verlag Otto Sagner, 427-436.

WeISS, DANIEL. 2008. Živi sebe normal'nenko! Zur Lexikalisierung von russ. sebe als Partikel. Schweizerische Beiträge zum XIV. Internationalen Slavistenkongress in Ohrid, September 20o8, 327-344. Zurich Open Repository and Archive, University of Zurich.

Wiklund, Anna-Lena. 1996. Pseudocoordination is subordination. Working Papers in Scandinavian Syntax 56, 29-54.

ZINKEN, Jörg. 2013. Reanimating responsibility. The weź- $\mathrm{V}_{2}\left(\right.$ take- $\left.\mathrm{V}_{2}\right)$ double imperative in Polish interaction. In: Nadine Thielemann \& Peter Kosta, eds., Approaches to Slavic Interaction, Amsterdam-Philadelphia: John Benjamins, 35-61.

Zinken, JöRG. 2016. Requesting Responsibility. The Morality of Grammar in Polish and English Family Interaction. Oxford: Oxford University Press. 


\section{Nicole Nau}

Adam Mickiewicz University in Poznań

Department of Scandinavian Studies

al. Niepodlegtości 4, PL-61-874 Poznań

naunicol@amu.edu.pl

\section{Kiroll Kozhanov}

Vilnius University

Institute for the Languages and Cultures of the Baltic

Universiteto 5, LT-o1131 Vilnius

kozhanov.kirill@gmail.com

\section{Liina Lindström}

University of Tartu

Institute of Estonian and General Linguistics

Ülikooli 18, EE-50ogo Tartu

liina.lindstrom@ut.ee

\section{Asta Laugalienè}

Vilnius University

Institute for the Languages and Cultures of the Baltic Universiteto 5, LT-01131 Vilnius

asta.zuklyte@flf.vu.lt

\section{Paweł Brudzyński}

University of Warsaw

Faculty of Polish Studies, KJowPiB

PL-oo-927 Warsaw

pawel.brudzynski@gmail.com 